\title{
The tectonostratigraphic evolution of Cenozoic basins of the Northern Tethys: The Northern margin of the Levant Basin
}

\author{
Nikolaos Papadimitriou $^{1,2,}{ }^{*}$, Remy Deschamps ${ }^{1}$, Vasilis Symeou ${ }^{1,2}$, Christine Souque ${ }^{1}$, Christian Gorini ${ }^{2}$, \\ Fadi Henri Nader ${ }^{1}$, and Christian Blanpied ${ }^{2}$ \\ ${ }^{1}$ Geosciences Division, IFP Energies nouvelles, 1-4, avenue de Bois-Préau, 92852 Rueil-Malmaison Cedex, France \\ 2 ISTeP, UMR 7193, CNRS, 75005 Paris, France
}

Received: 30 April 2018 / Accepted: 5 November 2018

\begin{abstract}
The easternmost part of the Mediterranean corresponds to a tectonically complex region which is linked with the convergence between Africa and Eurasia. The tectonostratigraphic evolution of this region is poorly constrained because of the absence of exploration wells. Cyprus is a crucial area to assess the link between the tectonic deformation and the consequent sedimentation in the Northern Levant margin. Paleogene and Neogene basins in the southern part of Cyprus record the main tectonic events related to the convergence of Africa and Eurasia. The objective of this contribution is to investigate the timing and the mechanisms of basin deformation, as well as the sedimentary infill of basins located onshore Cyprus and finally resolve how their evolution is linked to the regional geodynamic events. Based on fieldwork studies we reconstructed the tectono-stratigraphic evolution of the Polis Basin and the Limassol Basin to propose a conceptual model for the evolution of the Northern Levant margin, in accordance with the main geodynamic events. It is expected that analysis of the Polis and Limassol depressions, and later comparison of them will also shed more lights on the impact of the substratum and how it is associated to the main tectonic events.
\end{abstract}

\section{Introduction}

Cyprus is located in the eastern corner of the Mediterranean Sea. It is $225 \mathrm{~km}$ long (E-W) and $95 \mathrm{~km}$ wide $(\mathrm{N}-\mathrm{S})$ and is bounded by the Cyprus Arc and Eratosthenes Seamount to the south and Turkey to the north (Fig. 1). Eratosthenes Seamount is the bathymetric expression of an isolated carbonate platform which appears to subduct beneath the Cyprus Arc (Papadimitriou et al., 2018; Robertson et al., 2012). The Cyprus Arc is a complex structure which records the opposite movement of African and Eurasian plates that extends from the Ionian islands of western Greece to Turkey, striking E-W (Glover and Robertson, 1998; Kinnaird, 2008; Robertson et al., 2009).

The opening and the closing of Neotethys are recorded onshore Cyprus by the formation and the subsequent obduction of the Troodos Ophiolites during the Late Cretaceous (Garfunkel, 1998, 2004; Robertson and Xenophontos, 1993; Stampfli and Borel, 2002). After the obduction of the Ophiolites, a series of smaller basins were formed (Kinnaird, 2008). These basins are: (a) Mesaoria Basin; (b) Psematismenos Basin (PSB), (c) Limassol Basin (LB), and (d) Polis Basin (PB) (Fig. 2A).

\footnotetext{
* Corresponding author: papsalokin@gmail.com
}

Different scenarios attempt to describe the tectonic evolution of the region after the obduction of Troodos Ophiolites. These scenarios referred to as (a) the advance collision model which is associated with thrusting and folding onshore Cyprus since the late Eocene (Calon et al., 2005a, b); (b) the subduction and incipient collision scenario that suggests a northward dipping subduction zone to the south of Cyprus during the late Oligocene to early Miocene and a recent collision of the Cyprus Arc with Eratosthenes Seamount (Robertson et al., 2012); (c) strike-slip scenario which depicts that the obduction of the Troodos Ophiolites and the formation of the Neogene basins is controlled by sinistral strike-slip (Harrison, 2008); (d) thrust belt forward propagation model which suggests successive compressional pulses since the early Miocene and a change to strike-slip in the early Pliocene and/or Early Pleistocene due to the westward movement of the Anatolia microplate (Reiche et al., 2016; Robertson et al., 2012; Symeou et al., 2017).

This study is focused on the impact of tectonics on sedimentation during the Miocene and is based on sedimentological investigations that were undertaken during two field campaigns in the Polis and Limassol basins (Fig. 2A). The Limassol and Polis basins are bounded by a transverse zone which extends from the Kouklia village to the Xeropotamos River (Fig. 2A). Monnet (2005) has 


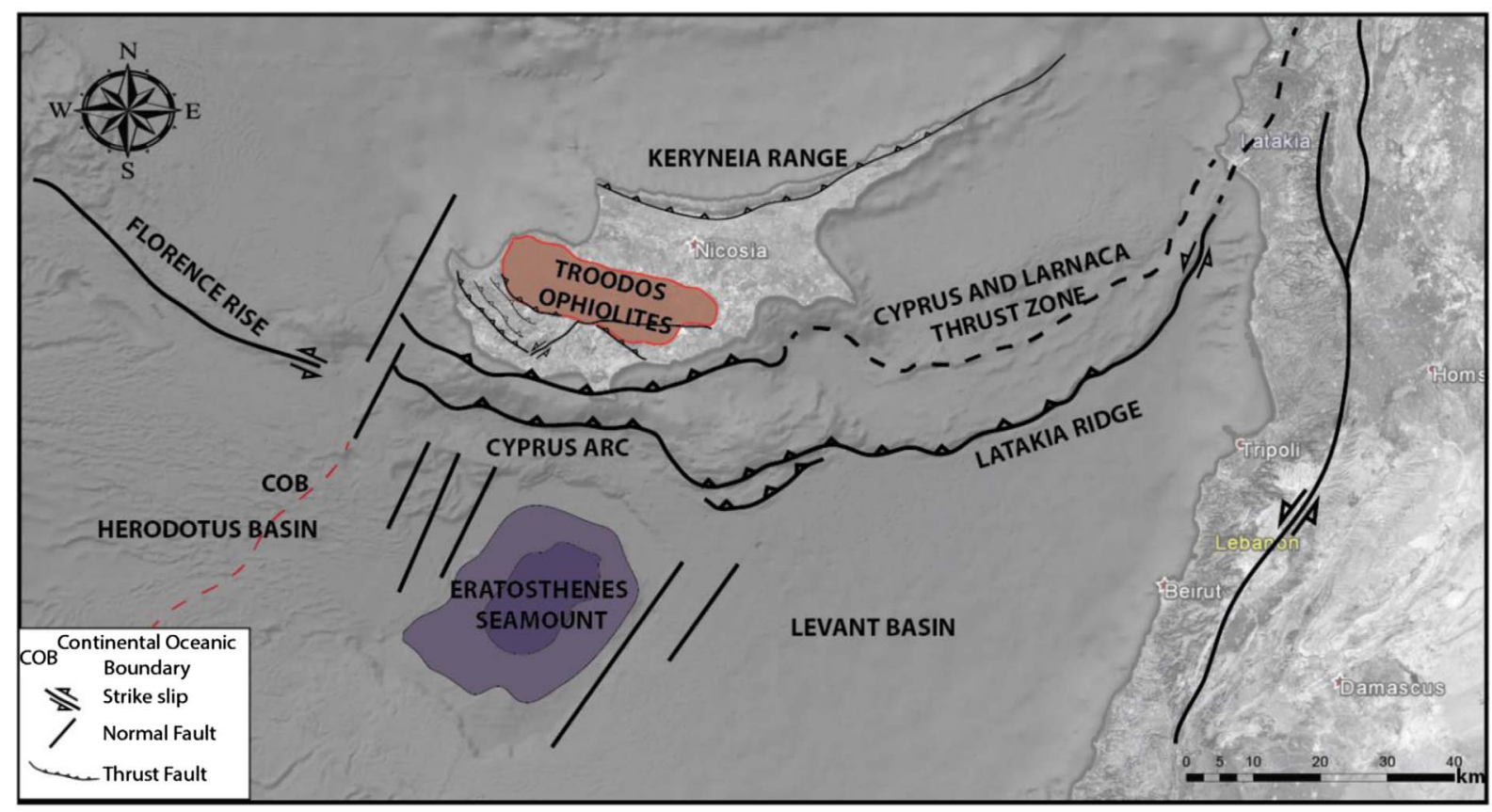

Fig. 1. Bathymetric map of the Eastern Mediterranean showing the topography as well as the most important structural elements bounding the Levant Basin (modified from Hawie et al., 2013).

shown that this zone has a sigmoid geometry due to the existence of a sinistral component on two main groups of thrusts located to the north and the south of the Mamonia Suture Zone (Fig. 1). It is expected that through basis analysis (Polis and Limassol basins), will also shed light on the impact of the substratum how it is linked with the main tectonic events that are recorded onshore Cyprus.

\section{Geological framework}

Recent tectonic reconstructions of the Eastern Mediterranean illustrated that different tectonic events influenced the island of Cyprus (Harrison et al., 2004; Kinnaird, 2008). The first episode occurred during the Late Cretaceous with the subduction of the African Plate beneath the Eurasian Plate and subsequent obduction of the Troodos Ophiolites (Dilek and Sandvol, 2009; Hawie et al., 2013; Kinnaird, 2008; Robertson et al., 2009, 2012).

The emplacement of the Troodos Ophiolites was succeeded by their juxtaposition with the Mamonia Complex (Bailey et al., 2000). The mechanism of the juxtaposition of the two complexes - Troodos Ophiolites and Mamonia Complexes - is still debated, and several models have been proposed (Bailey et al., 2000; Lapierre et al., 2007; Malpas et al., 1992, 1993; Robertson and Woodcock, 1979). Paleontological results of sediments that pre- and post date this tectonic event indicate that the juxtaposition ended during the Maastrichtian (Bailey et al., 2000).

From the late Maastrichtian until the late Eocene, Cyprus was covered by deep marine sediments rich in planktonic foraminifera and calcareous nannofossils, which correspond to the first three members of the Lefkara Formation (Kähler and Stow, 1998; Kinnaird, 2008; Robertson, 1977; Fig. 3). The Lefkara Formation is subdivided into four (4) geological units: (a) the Lower Marl Unit consists of pinkish marls, (b) the Chalk and Chert Unit, (c) the Chalk Unit, and (d) the Upper Marl Member which is composed of marly chalks (Kähler and Stow, 1998; Fig. 3). Robertson (1977) identified some in-situ benthic foraminifera in the upper levels of this unit and proposed a gradual shallowing of the area during the late stages of Eocene (Fig. 3).

The transition between the Lefkara (Paleogene) and the overlying Pakhna (Miocene) formations is highly connected the collision between the African and the Eurasian plates (Dercourt et al., 1986; Jolivet and Faccenna, 2000). In some places, there is a gradual change in the depositional environment, whereas in others the transition is marked by erosional surfaces (Follows, 1992, 1996). Pakhna Formation shows a lateral change in facies from reefs to hemipelagit and turbiditic deposits (Eaton and Robertson, 1993; Payne and Robertson, 1995; Fig. 3). The reefs referred to as the Terra and the Koronia members and can be found at the base and the top of the Miocene succession (BouDagher-Fadel and Lord, 2006; Follows, 1992, 1996; Fig. 3). Early Miocene reefs grew as upstanding patches under a relatively deep and calm sea, on isolated carbonate shelves (BouDagher-Fadel and Lord, 2006; Follows, 1992) and consist of several coral framestones (e.g., faviids sp. and Porites sp.). In contrast, the Koronia Member is a bindstone that is comprised of monospecific, laminar poritid corals (Follows, 1996) and 


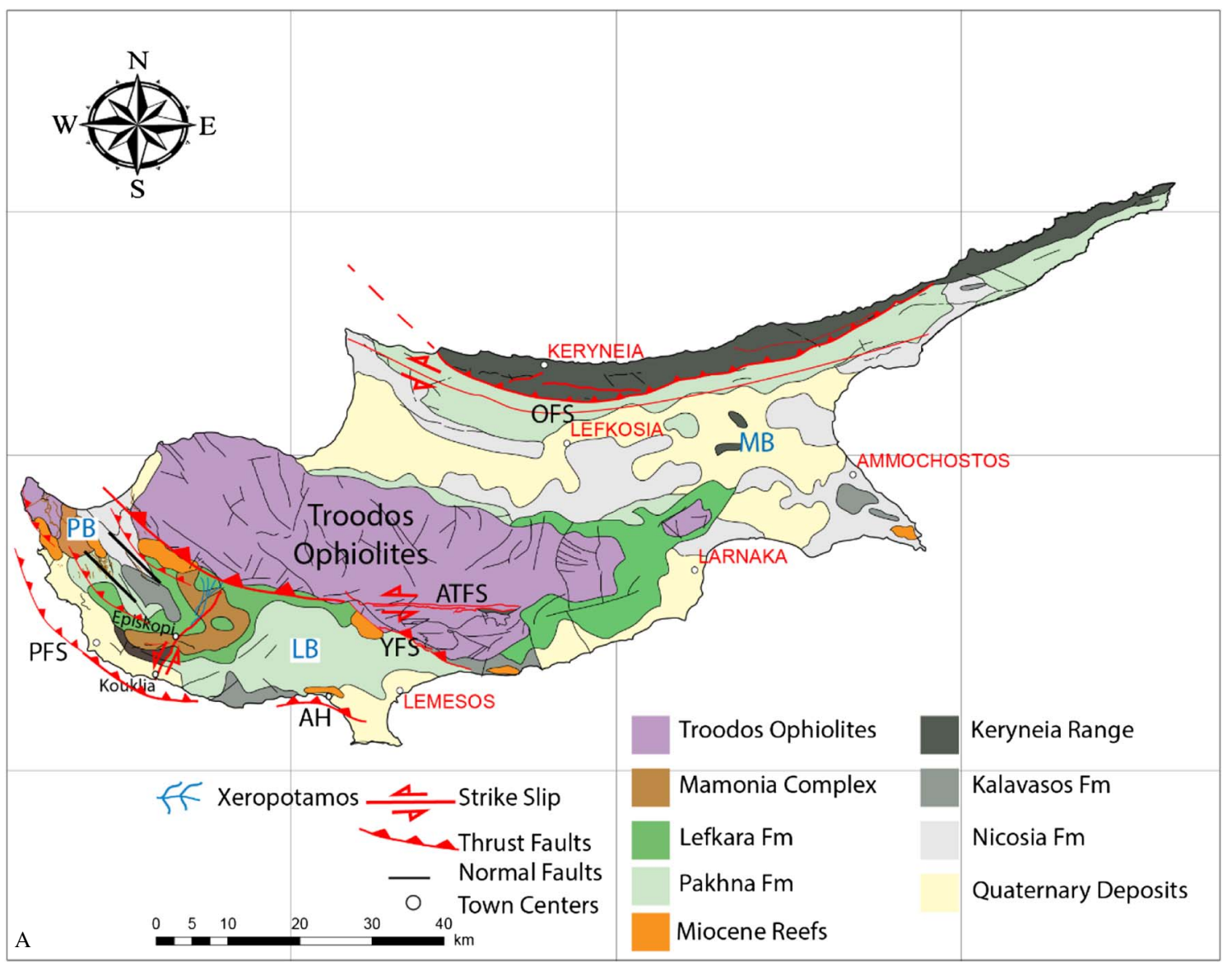

\begin{tabular}{|c|c|c|c|c|c|}
\hline Location & Dataset & $\begin{array}{c}\text { Coordinates of the main studied } \\
\text { location }\end{array}$ & Elevation & $\begin{array}{l}\text { Total } \\
\text { thickness }\end{array}$ & Purpose \\
\hline Polis Basin & Field section & $34^{\circ} 55^{\prime} 33.81^{\prime \prime} \mathrm{N} ; 32^{\circ} 24^{\prime} 57.09^{\prime \prime} \mathrm{E}$ & $340 \mathrm{~m}$ & $320 \mathrm{~m}$ & \multirow{7}{*}{ 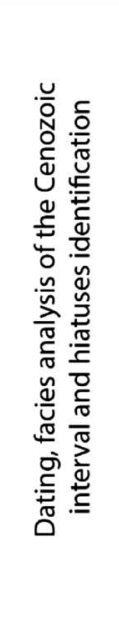 } \\
\hline Stractural Unit 1 & Wells & $\begin{array}{l}(1994 / V I 8) 32^{\circ} 21^{\prime} 51.537^{\prime \prime} E 34^{\circ} 53^{\prime} 43.235^{\prime \prime} \mathrm{N} \\
(1994 / V 10) 32^{\circ} 22^{\prime} 1.092^{\prime \prime} E 34^{\circ} 54^{\prime} 0.786^{\prime \prime} \mathrm{N}\end{array}$ & $\begin{array}{l}200 \mathrm{~m} \\
360 \mathrm{~m}\end{array}$ & $\begin{array}{l}180 \mathrm{~m} \\
200 \mathrm{~m}\end{array}$ & \\
\hline Stractural Unit 2 & Field section & $35^{\circ} 1{ }^{\prime} 36.80^{\prime \prime} \mathrm{N} ; 32^{\circ} 19^{\prime} 39.60^{\prime \prime} \mathrm{E}$ & $240 \mathrm{~m}$ & $280 \mathrm{~m}$ & \\
\hline Stractural Unit 3 & Wells & $\begin{array}{ll}(2004 / 015) & 32^{\circ} 26^{\prime} 4.29^{\prime \prime} \mathrm{E} 34^{\circ} 56^{\prime} 20.241^{\prime \prime} \mathrm{N} \\
(1980 / 076) & 34^{\circ} 58^{\prime} 3.48^{\prime \prime} \mathrm{N} ; 32^{\circ} 28^{\prime} 3.12^{\prime \prime} \mathrm{E}\end{array}$ & $\begin{array}{l}520 \mathrm{~m} \\
180 \mathrm{~m}\end{array}$ & $\begin{array}{l}150 \mathrm{~m} \\
300 \mathrm{~m}\end{array}$ & \\
\hline Stractural Unit 4 & Field section & $34^{\circ} 58^{\prime} 36.30^{\prime \prime} N ; 32^{\circ} 28^{\prime} 24.60^{\prime \prime} \mathrm{E}$ & $700 \mathrm{~m}$ & $240 \mathrm{~m}$ & \\
\hline $\begin{array}{l}\text { Limassol Basin } \\
\text { Paramali Section }\end{array}$ & Field section & $\begin{array}{l}34^{\circ} 39^{\prime} 50.48^{\prime \prime} \mathrm{N} ; 32^{\circ} 38^{\prime} 13.30^{\prime \prime} \mathrm{E} \\
34^{\circ} 41^{\prime} 12.51^{\prime \prime} \mathrm{N}, 32^{\circ} 41^{\prime} 24.64^{\prime \prime} \mathrm{E} \\
34^{\circ} 45^{\prime} 14.42^{\prime \prime} \mathrm{N}, 32^{\circ} 41^{\prime} 19.12^{\prime \prime} \mathrm{E}\end{array}$ & $\begin{array}{r}20 \mathrm{~m} \\
100 \mathrm{~m} \\
20 \mathrm{~m}\end{array}$ & $350 \mathrm{~m}$ & \\
\hline $\begin{array}{l}\text { Koilani Section } \\
\text { B }\end{array}$ & Field section & $34^{\circ} 50^{\prime} 15.52^{\prime \prime} \mathrm{N} ; 32^{\circ} 51^{\prime} 31.12^{\prime \prime} \mathrm{E}$ & $300 \mathrm{~m}$ & $900 \mathrm{~m}$ & \\
\hline
\end{tabular}

Fig. 2. [A] Simplified geological map of Cyprus illustrating the distribution of the basement terranes: the Troodos Ophiolites in purple, the Mamonia Complex in brown, the Keryneia Range in grey - and sedimentary cover and the main sedimentary basins. A distinction is made between circum-Troodos and circum-Keryneia sediments. Abbreviations as follows: AL - Akrotiri Lineament; YFS - Yerasa Fault System; OFS - Ovgos Fault System; ATFS - Arakapas Transform Fault; PFS - Pafos Fault System; LB Limassol Basin; PIB - Pissouri Basin; PSB - Psematismenos Basin; PB - Polemi Basin (modified from Kinnaird, 2008); [B] Overview of the dataset used for the present study. 


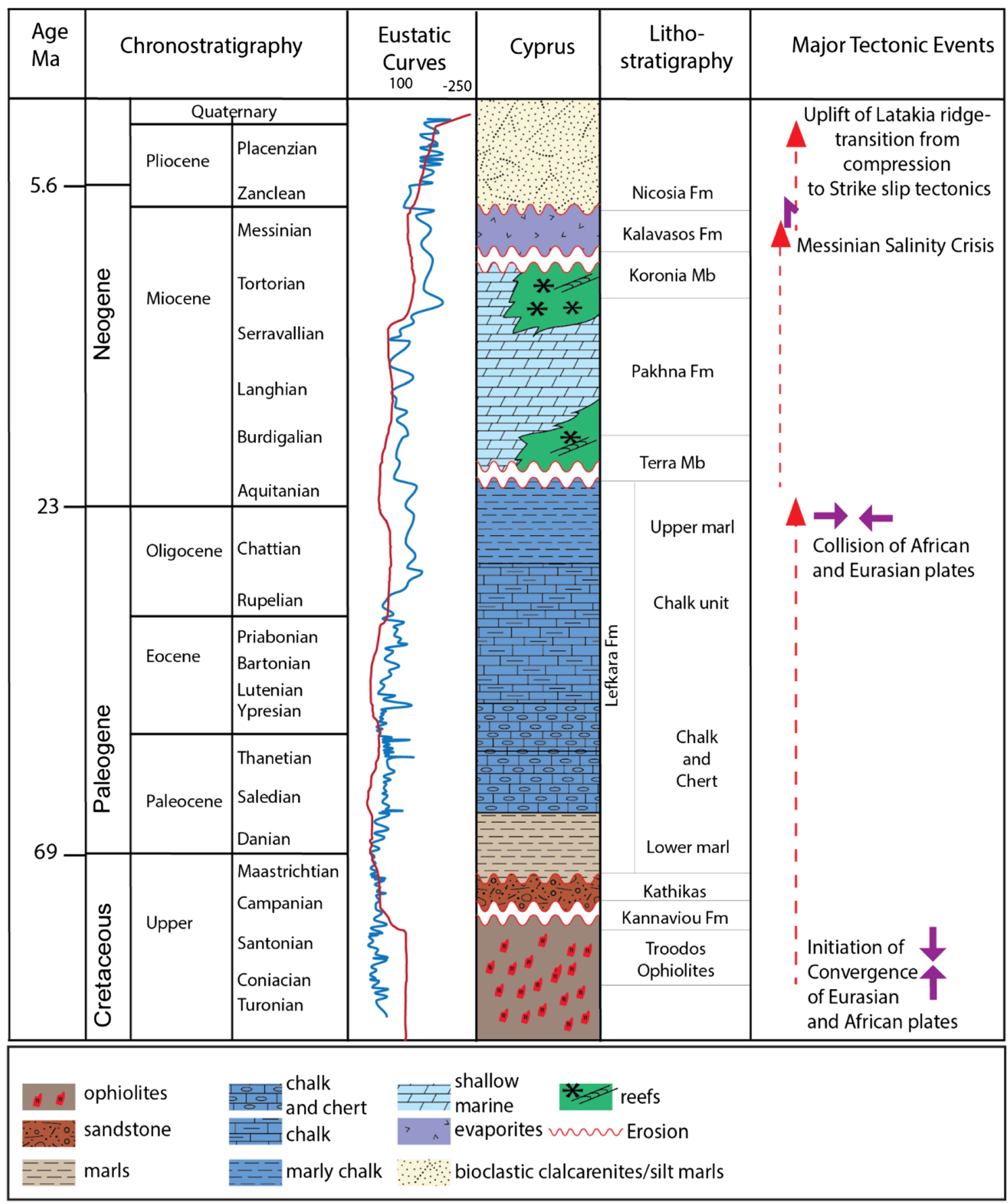

Fig. 3. A synthesized chronostratigraphic chart with the main lithologies onshore Cyprus (modified from Kinnaird, 2008).

was developed in a shallower sea with varying turbulence (Fig. 2B).

Pakhna Formation is overlain by Messinian deposits (Kalavasos Formation) which are exposed in localized depocenters such as Polemi, Pissouri, and Psematismenos, and they consist of alternating sapropels, marls and carbonates (Manzi et al., 2016; Figs. 2 and 3). Finally, the evaporitic sequence is succeeded by the calcarenites and the relatively deep-water marls of the Nicosia Formation, which in turn passes into stacked fluvial deposits that consist of well-bedded gravels, flood deposits, and palaeosols (Kinnaird, 2008; Figs. 2 and 3). 


\section{Methodology}

In order to propose a conceptual model which illustrates the major geodynamic events and their impact on sedimentary processes, fieldwork in the southern part of Cyprus was carried out.

The field campaigns were focused on the description of the lithology and the stratigraphic contacts between the Paleogene and Miocene formations (Figs. 2 and 4). During the fieldwork six (6) composite sedimentary logs were completed in the two areas of interest and sixty-five (65) sediment samples were recovered (Fig. 2B). The locations of logging were thoroughly chosen based on accessibility, dating requirements (to constrain the Upper Cretaceous to Pliocene rock successions), and variety of the facies attested during the Miocene. Thirty-five (35) samples were used for dating to have a better time constraint regarding the continuity of stratigraphic contacts and the sedimentary facies extent (Fig. 2B). In particular nannofossil analyses involved counting all specimens within a standard traverse (60 fields of view at $\times 1000$ magnification) as well as scanning of the rest of the slide for rare species. Each of the samples is dated using only refined versions of the "standard" published biostratigraphic zonation schemes (Martini, 1971; Sissingh, 1977, 1978). Moreover, petrography studies have been conducted to examine the microtextural features of the studied rock interval. For petrographic studies, sixty-five (65) thin sections were prepared and studied with a polarizing microscope at 1250 magnifications, following the Dunham's classification. Also, the fieldwork was supported by hydrogeological, exploration and geotechnical boreholes which are drilled by the Geological Survey Department of Cyprus (GSD) and provide subsurface data on borehole chips or boreholes cores. These drillings resulted in borehole data ranging up to $300 \mathrm{~m}$ that are used here in order to document the basement of the Polis Basin. Out of the provided data (courtesy of $G S D$ ), four boreholes were chosen and analyzed for the purposes of this study (Fig. 4).

\section{Results}

Five (5) facies associations are identified onshore Cyprus from the Late Cretaceous until the Pliocene period. Each of the defined facies allowed us to define the characteristics for the formations recognized onshore Cyprus and portray the architecture of Polis and Limassol basins since the Paleogene.

\subsection{Facies analysis}

\subsubsection{Intertidal deposits}

Facies association 1

Fa $1 \mathrm{~A}$

Description. Fa $1 \mathrm{~A}$ is characterized by an alternation of clays $(0.2 \mathrm{~m})$ with cross-bedded $(0.2 \mathrm{~m})$, bioclastic, dolomitized grainstones (Fig. 5.1). The laminated clays show traces of mud-cracks and contain flat pebbles (Fig. 5.1B), while at the base of the section, the grainstones show traces of mega ripples (Fig. 5.1D).

Interpretation. This facies refers tidal-flat deposits which are mainly found in the intertidal zone. Exposures of this facies are mainly located along the northern parts of Limassol Basin $\left(34^{\circ} 43^{\prime} 19.76^{\prime \prime} \mathrm{N} ; 33^{\circ} 1^{\prime} 2.19^{\prime \prime} \mathrm{E}\right)$.

\section{Fa 1B}

Description. Fa 1B consists of massive, parallel beds of coarse-grained, bioclastic grainstones, alternating with bioturbated wackestones rich in benthic foraminifera (Figs. 5.2B and C). Bioturbation is occasionally identified and corresponds to Thalassinoides burrows (Eaton and Robertson, 1993).

Interpretation. The grain textures of these rock units, as well as the traces of Thalassinoides, suggest a shallow, highenergy environment and more particular it represents sand shoal deposits (Table 1). The bioclastic material was mostly derived from patch reefs. In contrast, the allochthonous calcarenites have been transported from the Troodos Ophiolites and/or the Mamonia Complex (Follows, 1992, 1996; Eaton and Robertson, 1993). Exposures of this facies are mainly located along the northern parts of Polis $\left(34^{\circ} 47^{\prime} 16.07^{\prime \prime} \mathrm{N} ; \quad 32^{\circ} 54^{\prime} 53.99^{\prime \prime} \mathrm{E}\right)$ and Limassol basins $\left(34^{\circ} 43^{\prime} 19.76^{\prime \prime} \mathrm{N} ; 33^{\circ} 1^{\prime} 2.19^{\prime \prime} \mathrm{E}\right)$.

\subsubsection{Barrier reef/open shelf deposits}

\section{Facies association 2}

Fa $2 A$

Description. Fa 2A corresponds to rudstone/boundstone interval with corals, red algae and bivalves (Fig. 2A) associated with bioclastic packstone (red algae and bivalve debris). The primary frame builders of this unit are the Porites sp. (Fig. 6.1B) which in some cases are abundant while in others their number decreases towards the top of the sequence, and they are replaced by Poritis sp. Secondary frame builders found in grainstone and rudstone textures (Fig. 6.1C) include red algae and small benthic foraminifera (miliolids, nummulitids, echinoderms, bivalves).

Interpretation. The presence of the in-situ corals (i.e., Porites sp.) reveals that these sediments deposited in a very shallow and protected euphotic environment (Fig. 6.1B and Table 1). Usually, this facies has been recognized in circular shape structures attaining a width of $100 \mathrm{~m}$ and a thickness of $80 \mathrm{~m}$ and has been described to present coral reefs (Fig. 6.1A).

\section{Fa 2B}

Description. Fa 2B facies presents grainstone grading into wackestones rich in red algae (Fig. 6.2B [1]) benthic foraminifera (Fig. 6.2B, i.e., [2] crinoids and [3] Lepidocyclina) and coral debris. Incisions of structureless rudstone units (1-2 m thick), with abundant bioclasts, bioturbation, benthic foraminifera (Fig. 6.2C; [4] miliolids) appear to cut this wackestone to grainstones beds.

Interpretation. This facies indicates a high-energy environment and the abundant red algae and coral fragments suggest a reef front setting (Fig. 6.2). Reef front deposits have been observed in a small distance from in-situ reefs of early Miocene age (i.e., Burdigalian, Terra Member), mainly in the Polis Basin $\left(34^{\circ} 53^{\prime} 27.35^{\prime \prime} \mathrm{N}, 32^{\circ} 21^{\prime} 56.77^{\prime \prime} \mathrm{E}\right)$. 


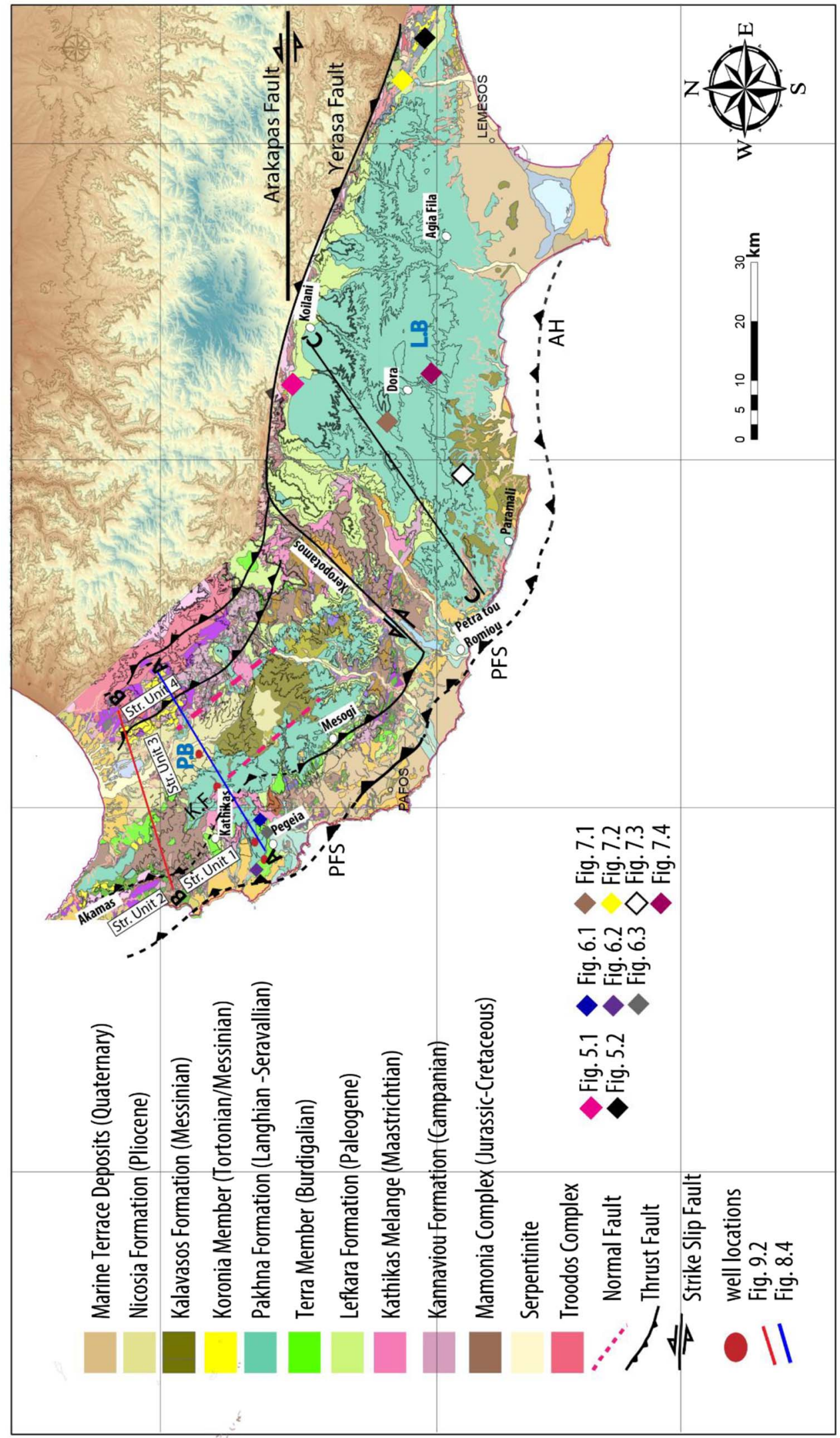

Fig. 4. Simplified geological map of the western part of Cyprus showing the main geologic formations with their ages (adapted from Cyprus Geological Survey Department, 1995). 

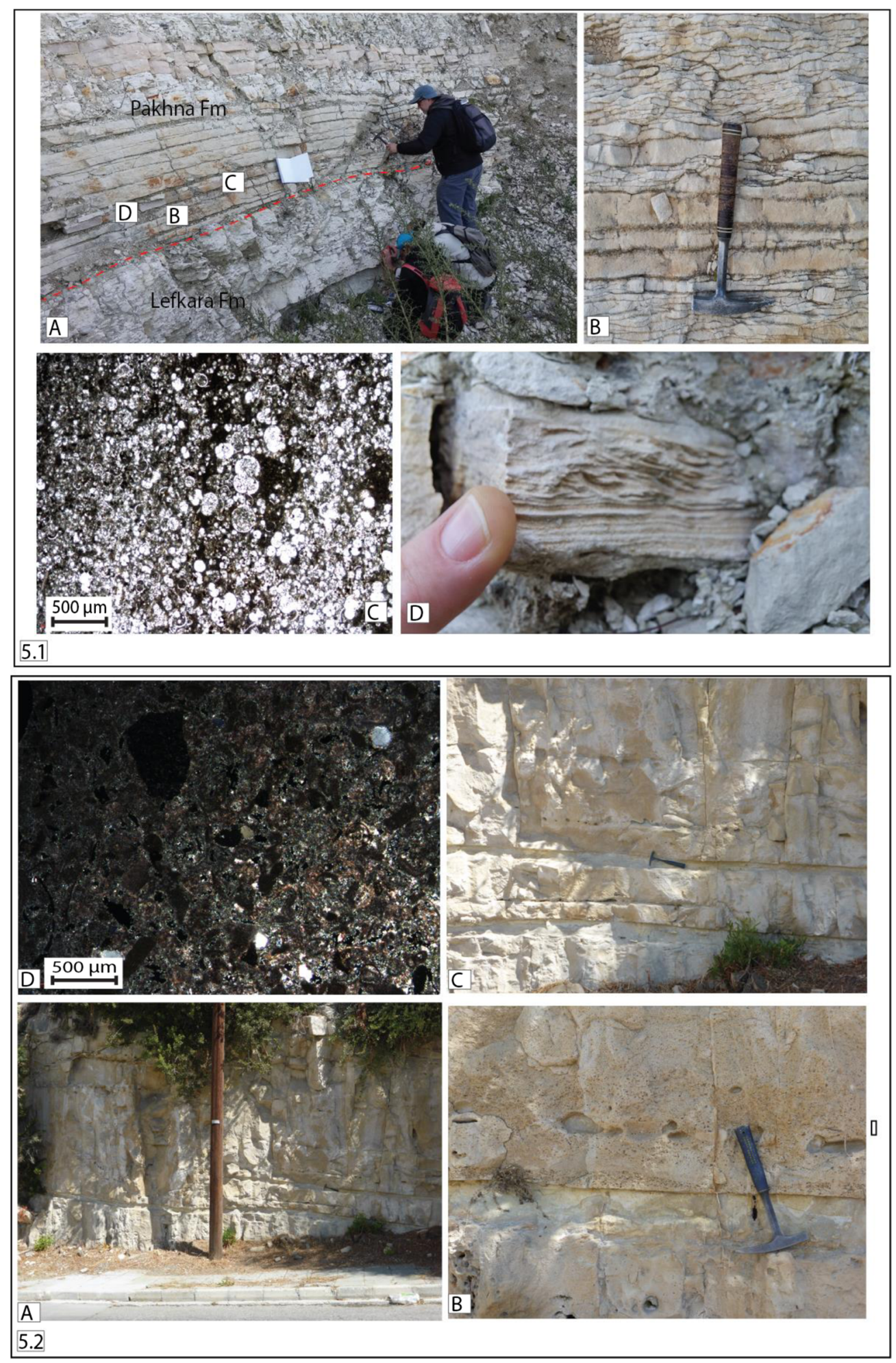

Fig. 5. [1] (A) Studied outcrop near Koilani village $\left(34^{\circ} 50^{\prime} 15.52^{\prime \prime} \mathrm{N} ; 32^{\circ} 51^{\prime} 31.12^{\prime \prime} \mathrm{E}\right)$; (B) Thin bedded bioclastic grainstones; (C) Photomicrographs (PPL - Plane Polarized) of packstone/grainstones with abundant benthic and pelagic foraminifera; (D) Traces of mega-ripples in a bioclastic grainstone; [2] (A) Studied outcrop of the upper Pakhna Formation in the eastern part of Limassol Basin (34 $\left.43^{\prime} 19.76^{\prime \prime} \mathrm{N} ; 33^{\circ} 1^{\prime} 2.19^{\prime \prime} \mathrm{E}\right)$; (B) Grainstones interbedded with wackestones; the base of the calcarenitic unit is composed of allochthonous grains; (C) Bioturbated w/p grading to grainstone; (D) Photomicrograph (PPL - Plane Polarized) of calcarenite with shell debris and quartz. 
Table 1. Summary of the facies associations' description and proposed depositional environments for the Upper Cretaceous to Upper Miocene rock interval of southern Cyprus.

\begin{tabular}{|c|c|c|c|c|}
\hline Facies associations & & & Facies description & Depositional environment \\
\hline \multirow[t]{2}{*}{ Restricted shallow marine } & $\mathrm{Fa} 1$ & $\mathrm{~A}$ & $\begin{array}{l}\text { Early dolomitized bioclastic grainstone with } \\
\text { current ripples and mega-ripples alternated by } \\
\text { bioturbated wackestone with some bioclasts } \\
\text { and mud cracks. }\end{array}$ & Tidal Flat \\
\hline & & $\mathrm{B}$ & $\begin{array}{l}\text { Alternation of bioclastic grainstone rich in } \\
\text { miliolids and some lepydocyclina with } \\
\text { bioturbated bioclastic wackestone to packstone. }\end{array}$ & Sand shoal \\
\hline \multirow[t]{2}{*}{ Barrier reef } & Fa 2 & $\mathrm{~A}$ & $\begin{array}{l}\text { Boundstone/bafflestone with red algae debris, } \\
\text { corals in place, Lepidocyclina and bioclasts. }\end{array}$ & Reef /Back-reef \\
\hline & & $\mathrm{B}$ & $\begin{array}{l}\text { Breccia (boundstone with red algae debris, } \\
\text { coral debris, large benthic foraminifera } \\
\text { (Lepidocyclina, bryozoans) occasional incisions. }\end{array}$ & Reef front \\
\hline Open shelf deposits & Fa 3 & $\mathrm{~A}$ & $\begin{array}{l}\text { Wackstones to packstones with an abundance } \\
\text { of benthic foraminifera, and bioclasts. Erosional } \\
\text { contact between the packstone and the } \\
\text { wackestone beds. }\end{array}$ & Open shelf \\
\hline \multirow[t]{3}{*}{ Slope deposits } & $\mathrm{Fa} 4$ & $\mathrm{~A}$ & $\begin{array}{l}\text { Intercalation of grainstone packstone beds } \\
\text { (highly bioturbated) with marls. }\end{array}$ & Slope Deposits/ turbidites \\
\hline & & $\mathrm{B}$ & $\begin{array}{l}\text { Large contorted fragments of laminated marls } \\
\text { and carbonates } 3,5 \mathrm{~m} \text { thick. }\end{array}$ & MTCs \\
\hline & & $\mathrm{C}$ & $\begin{array}{l}\text { Bioclastic grainstones which are fining upwards } \\
\text { and intercalated with a marly laminated unit } \\
\text { including benthic foraminifera. }\end{array}$ & $\begin{array}{l}\text { Toe of the upper slope } \\
\text { (contourites) }\end{array}$ \\
\hline Basin & $\mathrm{Fa} 5$ & $\mathrm{~A}$ & $\begin{array}{l}\text { Mudstone to wackestone with bioclasts, pelagic, } \\
\text { traces of zoophycos. }\end{array}$ & Basinal setting \\
\hline
\end{tabular}

\section{Facies association 3}

\section{Fa 3 A}

Description. Fa $3 \mathrm{~A}$ consists of highly-bioturbated packstones, intercalated with less bioturbated wackestones (Fig. 6.3). Both packstones and wackestones are rich in benthic ([2] crinoids [3] Lepidocyclina) and planktonic foraminifera ([6] Globigerina; Fig. 6.3C) as well as shell debris (Fig. 6.3). Red algae debris is only occasionally present (Fig. 6.3D), whereas coral fragments are absent. The variety of fauna in these textures (bivalves, and benthic foraminifera, such as (Fig. 6.3D [3] Lepidocyclina and [2] crinoids), indicate normal salinities and, thus, open-shelf conditions (Table 1).

Interpretation. This facies is interpreted as open shelf deposits which are mainly exposed in the Pegeia region (i.e., in the western side of the Polis Basin $34^{\circ} 53^{\prime} 10.57^{\prime \prime} \mathrm{N}$, $\left.23^{\circ} 20^{\prime} 52.2^{\prime \prime} \mathrm{E}\right)$.

\subsubsection{Slope-deep marine deposits}

Facies association 4

Fa 4A

Description. Fa $4 \mathrm{~A}$ is represented by alternations of bioturbated marlstone with packstones (Figs. 7.1A and B). This unit is highly-bioturbated, with abundant foraminifera (benthic and planktonic) and shell debris (Fig. 7.1C). The packstones are cross-bedded and have sharp contacts with the laminated marls (Figs. 7.1A and B).

Interpretation. The erosional surface at the base of the grainstones and their gradual upward fining suggest that this sedimentary facies corresponds to proximal slope turbiditic deposits. However, the absence of water escapestructures and sole-marks, suggest that these sediments correspond to calciturbidites (Table 1). Previous works have defined that these sediments are Pakhna Formation equivalents and are mainly exposed in the Limassol Basin (Eaton and Robertson, 1993; Kinnaird, 2008).

\section{Fa 4B}

Description. Fa 4B consists of bioclastic grainstones, which fine upwards, and are intercalated with laminated marls (Figs. 7.2A and B). The whole unit is highly-bioturbated and contains abundant planktonic foraminifera (Fig. 7.2A) and is found in the small cyclic sequences (Fig. 7.2C). Moreover, the grainstones are cross-bedded, while the sedimentary structures faint upwards.

Interpretation. The description given for these deposits, seem to agrees with the description that was proposed by Stow and Lovell (1979) and Stow et al., (2002) for contourite systems (Table 1). Kähler and Stow (1998) have shown strong evidence for deposition of contourites from the early (eastern part of the island) and late Oligocene (western part of the island) until the early Miocene. 

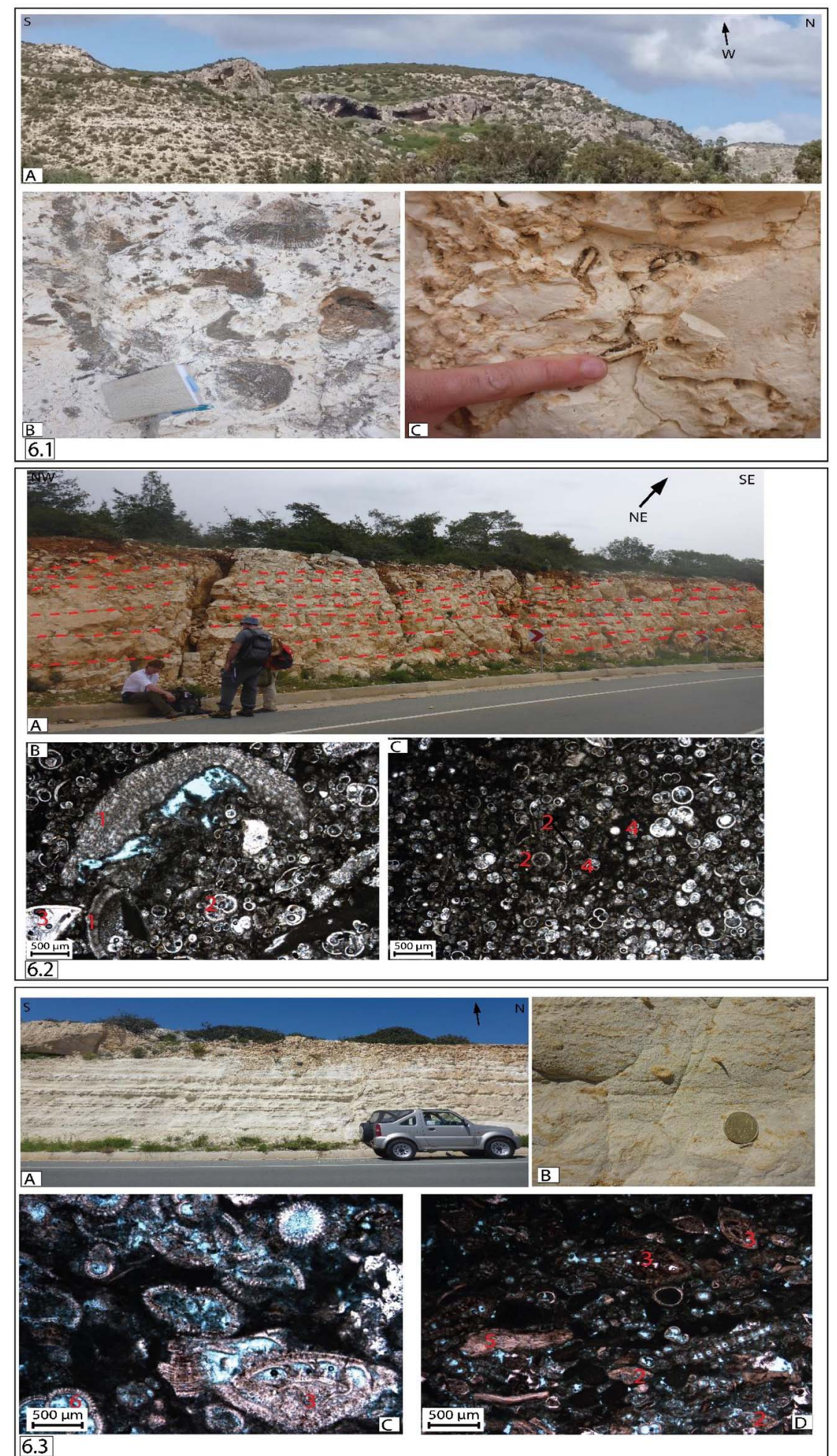

Fig. 6. [1] (A) Reef limestones found near the Androlykou quarry $\left(35^{\circ} 0^{\prime} 0.91^{\prime \prime} \mathrm{N} ; 32^{\circ} 23^{\prime} 7.70^{\prime \prime} \mathrm{E}\right)$; (B) Photograph showing corals that are probably in place; (C) Photograph showing coral fragments in a boundstone; [2] (A) Photograph showing a studied outcrop of reef front deposits in the Pegeia region $\left(34^{\circ} 53^{\prime} 27.35^{\prime \prime} \mathrm{N}, 32^{\circ} 21^{\prime} 56.77^{\prime \prime} \mathrm{E}\right)$; (B) Photomicrograph (PPL - Plane Polarized) of a packstone to grainstone with benthic foraminifera ([1] red algae cross-section; [2] crinoids; [3] Lepidocyclina; [4] miliolids) (C) Photomicrographs (PPL - Plane Polarized) of (C) Packstone with medium to low porosity; [3] (A) Studied outcrop of open shelf deposits (Fa 3A) in the Pegeia region $\left(34^{\circ} 53^{\prime} 10.57^{\prime \prime} \mathrm{N} ; 23^{\circ} 20^{\prime} 52.2^{\prime \prime} \mathrm{E}\right)$; (B) Wackestone with some bioturbation; (C, D) Photomicrographs (PPL - Plane Polarized) of (C) Packstone with medium to low porosity ([2] crinoids; [3] Lepidocyclina; [6] Globigerina planktonic foraminifera); (D) Packstone with benthic foraminifera ([3] Lepidocyclina; [4] miliolids; [5] red algae). 

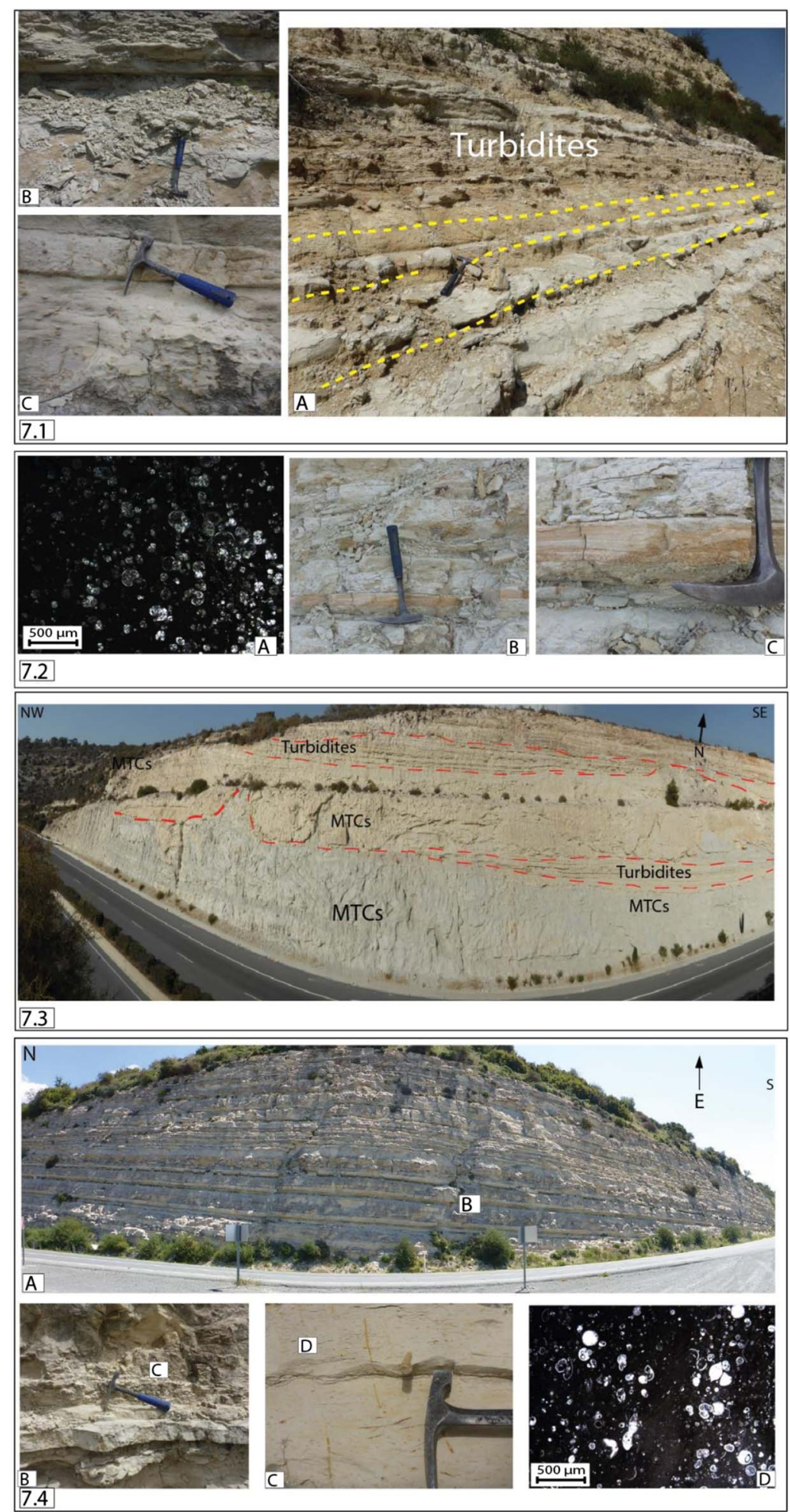

Fig. 7. [1] (A) Photograph showing a turbidite system in the Limassol Basin $\left(34^{\circ} 48^{\prime} 23.30^{\prime \prime} \mathrm{N} ; 32^{\circ} 47^{\prime} 29.49^{\prime \prime} \mathrm{E}\right)$; (B) Wackestone grading to packstone; (C) Highly bioturbated mudstone grading to packstone; [2] (A) Micritic non-porous mudstone, rich in pelagic foraminifera; (B) Cross-bedded grainstones fining to marlstones; (C) Mudstone overlain by gross bedded grainstones suggesting the initiation of a new cycle; [3] (A) Panoramic view of the MTCs identified along the Limassol-Pafos highway (34 $45^{\prime} 21.30^{\prime \prime} \mathrm{N}$; $\left.34^{\circ} 45^{\prime} 21.30^{\prime \prime} \mathrm{E}\right)$; [4] (A) Studied outcrop of basinal sediments near Monagri village $\left(34^{\circ} 47^{\prime \prime} 16.07^{\prime \prime} \mathrm{N} ; 32^{\circ} 54^{\prime} 53.99^{\prime \prime} \mathrm{E}\right)$; (B) Alternations of mudstone/wackestones with packstones; (C) Highly bioturbated mudstone; (D) Photomicrograph (PPL - Plane Polarized) of wackestone with benthic and planktonic foraminifera. 


\section{Fa 4C}

Description. Fa $4 \mathrm{C}$ is described by chaotic intervals, usually $3.5 \mathrm{~m}$ thick, which are composed of large, contorted fragments of laminated marls (Fig. 7.3). These chaotic intervals, pinch out on both sides and are characterized by a basal shear zone (30-150 m long), as well as upward curved or stepped margins, indicating several distinct lobes.

Interpretation. The Fa $4 \mathrm{C}$ has been interpreted as Mass Transport Complexes (MTCs; Eaton and Robertson, 1993; Lee and Stow (2007); Lord et al., 2009). The MTCs have mainly been identified in the western and eastern sides of the Limassol Basin. In the western part of the Limassol Basin the MTCs are found along the recently constructed Limassol-Pafos highway (Fig. 7.3; $34^{\circ} 41^{\prime} 34.66^{\prime \prime} \mathrm{N}$; $\left.32^{\circ} 51^{\prime} 53.47^{\prime \prime} \mathrm{E}\right)$ as well as in an outcrop $4 \mathrm{~km}$ north from Anogyra village $\left(34^{\circ} 45^{\prime} 13.72^{\prime \prime} \mathrm{N} ; 32^{\circ} 41^{\prime} 12.99^{\prime \prime} \mathrm{E}\right)$. Biostratigraphy results from Lee and Stow (2007), Lord et al., (2009) and Kinnaird (2008) have shown that the MTCs are interbedded with late Miocene sediments.

\section{Fa 5A}

Description. This facies consists of thin, alternating beds of wackestone and marls, interbedded with packstones (Fig. 7.4A). All of the packstones and wackestones are highly bioturbated, with benthic and planktonic foraminifera and bioclasts (Figs. 7.4B-D).

Interpretation. The bioturbation found in these textures is characterized by Zoophycos, Chondrites and Planolites suggesting a deep-water setting (e.g., open shelf; 700-1100 m; Eaton and Robertson, 1993). This facies is exposed in several outcrops in Limassol Basin and marks the most common appearance of Pakhna equivalent. These outcrops are also described by Eaton and Robertson, (1993) and are referred to as Basin-plain Association. In particular, they described these sediments as off-white with a high planktonic/benthic foraminifera ratio (i.e., 85-95\% Eaton, 1987; Eaton and Robertson, 1993).

\subsection{Architecture of the basins in southern Cyprus}

Through the sedimentological, the structural observations as well as spatial distribution of the facies association we propose a new tectonostratigraphic framework of these two basins and attest the different controlling factors (such as tectonics, eustatism, and paleoenvironmental conditions), which contribute into the geological evolution of the southern part of Cyprus.

\subsubsection{Polis Basin}

The Polis Basin is located in the westernmost part of Cyprus (Figs. 2 and 4). To the west, the topography of the basin (i.e., the Structural unit 1 - Pegeia region) is controlled by N-S trending thrusts (Fig. 4). Similarly, to the north (i.e., Structural unit 2-Akamas Peninsula), the late Miocene reefs are occasionally sitting on top of the Mesozoic sediments (Fig. 4). The largest Structural unit 3 in the Polis Basin is referred to as "Polis Graben" and corresponds to an asymmetrical depression NNW-SSE oriented that is approximately $20 \mathrm{~km}$ at its widest point
(Fig. 4). Finally, the Structural unit 4 is located along the eastern flank of Polis Graben along NW-SSE trending faults (Fig. 4).

\section{Structural unit 1 (Pegeia region)}

The Pegeia region is bounded to the northeast by the Kathikas Formation which is juxtaposed to the Quaternary marine terraces (Fig. 4). The boundary between the Lefkara and Pakhna formations found in this region is unconformable (Fig. 8.1). For instance, the Late Cretaceous sediments are overlain by the Miocene Formation while the Paleogene succession (Lefkara Formation), is locally absent (Figs. 8.1A-C). This contact also appears to be diachronous. In particular, towards the coastline, the early Miocene sediments rest unconformably on top of the Lefkara Formation (Fig. 8.1) while towards the east (i.e., Kathikas village; Fig. 4) the Lefkara Formation pinches on the slopes of the Kathikas Formation (Fig. 4).

\section{Cretaceous}

Swarbrick and Naylor, 1980 observed that the Cretaceous is (lowest part of the composite log in Fig. 8.1A) is composed of poorly sorted brownish to grey clasts supported by argillaceous matrix. The beds of this interval are 1-3 m thick, and they can be defined by the variation in the size of clasts and fabrics, or the interbeds of pelagic chalks (Fig. 8.1A). Coccolith fragments and foraminifera found within the pelagic chalks dated back to late Maastrichtian indicating pauses in debris flow sedimentation (Urquhart and Banner, 1994; Morse, 1996). We propose that these sediments are deposited in a deep marine bathyal setting as a result of gravitational forces.

\section{Paleogene}

The Cretaceous interval is overlain by a sequence which consists of alternations of wackestone to mudstone beds, with pelagic foraminifera (40-120 m, Fig. 8.1A) suggesting basinal deposits (Fa 5A). Biostratigraphy results have shown that these sediments were deposited during the early Eocene (Kähler, 1994).

\section{Early Miocene}

The Eocene-Miocene stratigraphic contact in the Pegeia region is occasionally erosive (Figs. $8.1 \mathrm{~B}$ and $\mathrm{C}$ ). The overlying unit (120-150 m, Fig. 8.1A) corresponds to reef front deposits ( $\mathrm{Fa} 2 \mathrm{~B}$ ). This facies is occasionally cut off by channelized conglomerate sheets (1-2 m thick), with an abundance of red algae fragments and bioclasts and is found in several locations (near Kathikas Village: $34^{\circ} 53^{\prime} 45.58^{\prime \prime} \mathrm{N}, 32^{\circ} 23^{\prime} 6.74^{\prime \prime} \mathrm{E}$; Pegeia village: $34^{\circ} 53^{\prime} 27.70^{\prime \prime} \mathrm{N}$; $\left.32^{\circ} 21^{\prime} 16.46^{\prime \prime} \mathrm{E}\right)$. The presence of the calcareous nannofossils such as Sphenolithus heteromorphus (restricted to Nannofossil Zones NN5-NN4), Helicosphaera ampliaperta, and $H$. scissura confirms an early Miocene age (Burdigalian; NN4a).

In-situ early Miocene reefs (Fa 2A; Table 1) have been identified along the south-western coastline of Cyprus and near Androlykou village (Fig. 4). The majority of these reefs appear to be $50 \mathrm{~m}$ thick, with few signs of deformation (i.e., breccia). 

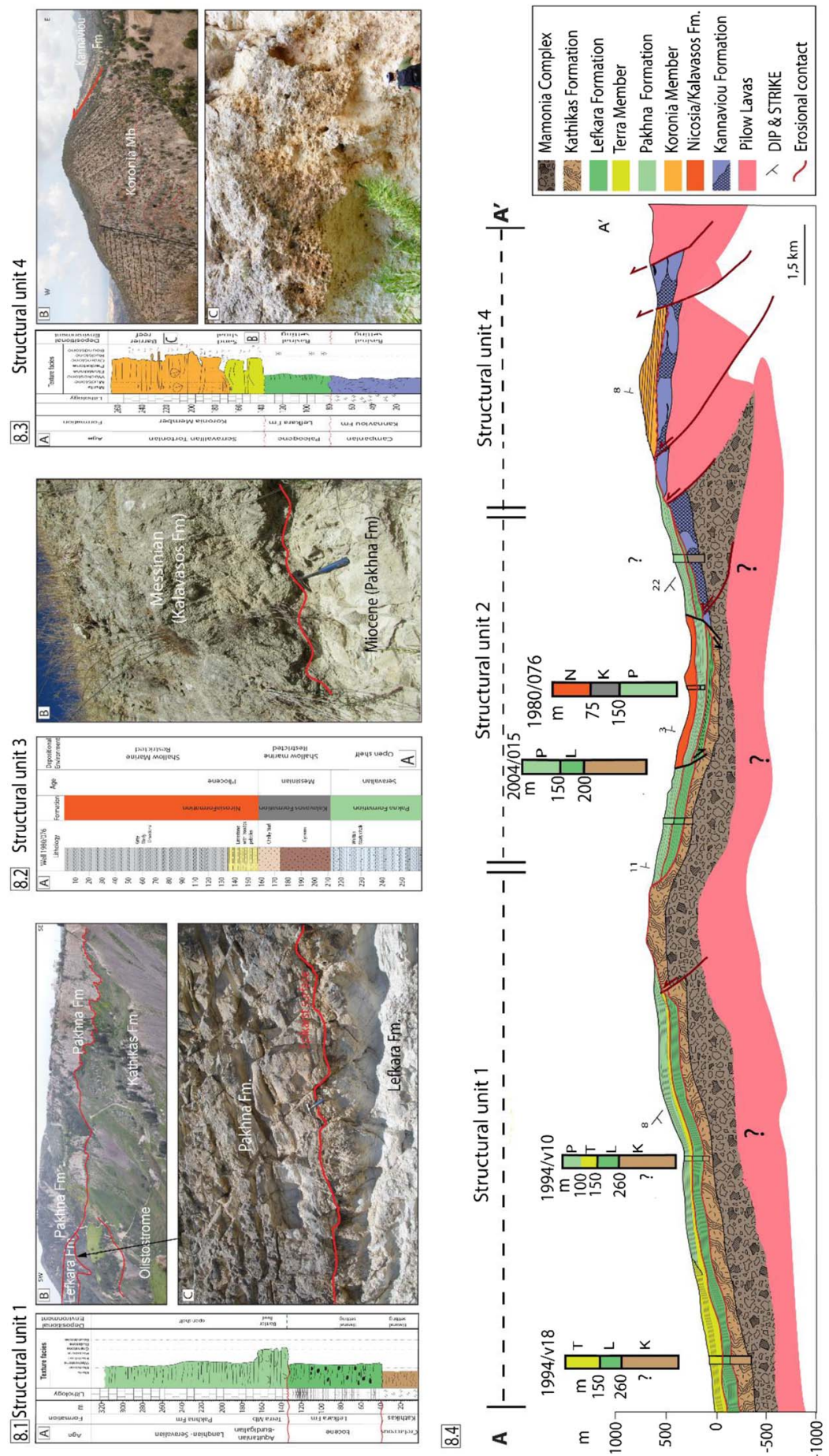

Fig. 8. [1] (A) Sedimentary log measured in the Pegeia region showing the main sedimentary facies from the Late Cretaceous to late Miocene as well as the ages subdivisions deduced from biostratigraphic analysis; (B) Panoramic view of the contact between the Miocene (Pakhna Fm), Paleogene (Lefkara Fm) and Late Cretaceous (Kathikas Fm) sediments. The contact between the Miocene and the Cretaceous sediments is shown by the red line $\left(34^{\circ} 55^{\prime} 33.81^{\prime \prime} \mathrm{N}\right.$; $\left.32^{\circ} 24^{\prime} 57.09^{\prime \prime} \mathrm{E}\right)$; (C) Karstification identified near Kathikas village. [2] (A) Synthetic log showing the main lithologies (interpreted during the present study) recovered from of the Borehole 1980/ 076; (B) Messinian evaporites on top of Miocene neritic carbonates in the southern part of Polis Graben near Theletra village $\left(34^{\circ} 54^{\prime} 36.40^{\prime \prime} \mathrm{N} ; 32^{\circ} 27^{\prime} 32.27^{\prime \prime} \mathrm{E}\right)$. [3] (A) Sedimentary log illustrating the main facies and the depositional environments in the eastern flank of Polis Basin; Panoramic view of the Koronia Member sitting on top of Late Cretaceous sediments in the north-eastern flank of Polis Basin (34 $59^{\prime} 59.59^{\prime \prime} \mathrm{N}$; 32 $\left.2^{\circ} 9^{\prime} 4.48^{\prime \prime} \mathrm{E}\right)$; (B) Massive boundstones of late Miocene reef (Koronia Member); [4] Cross-section intersecting Polis Basin: (A) SW-NE cross-section intersecting the southern part of Polis Basin from Pegeia region to the Pelathousa village. 


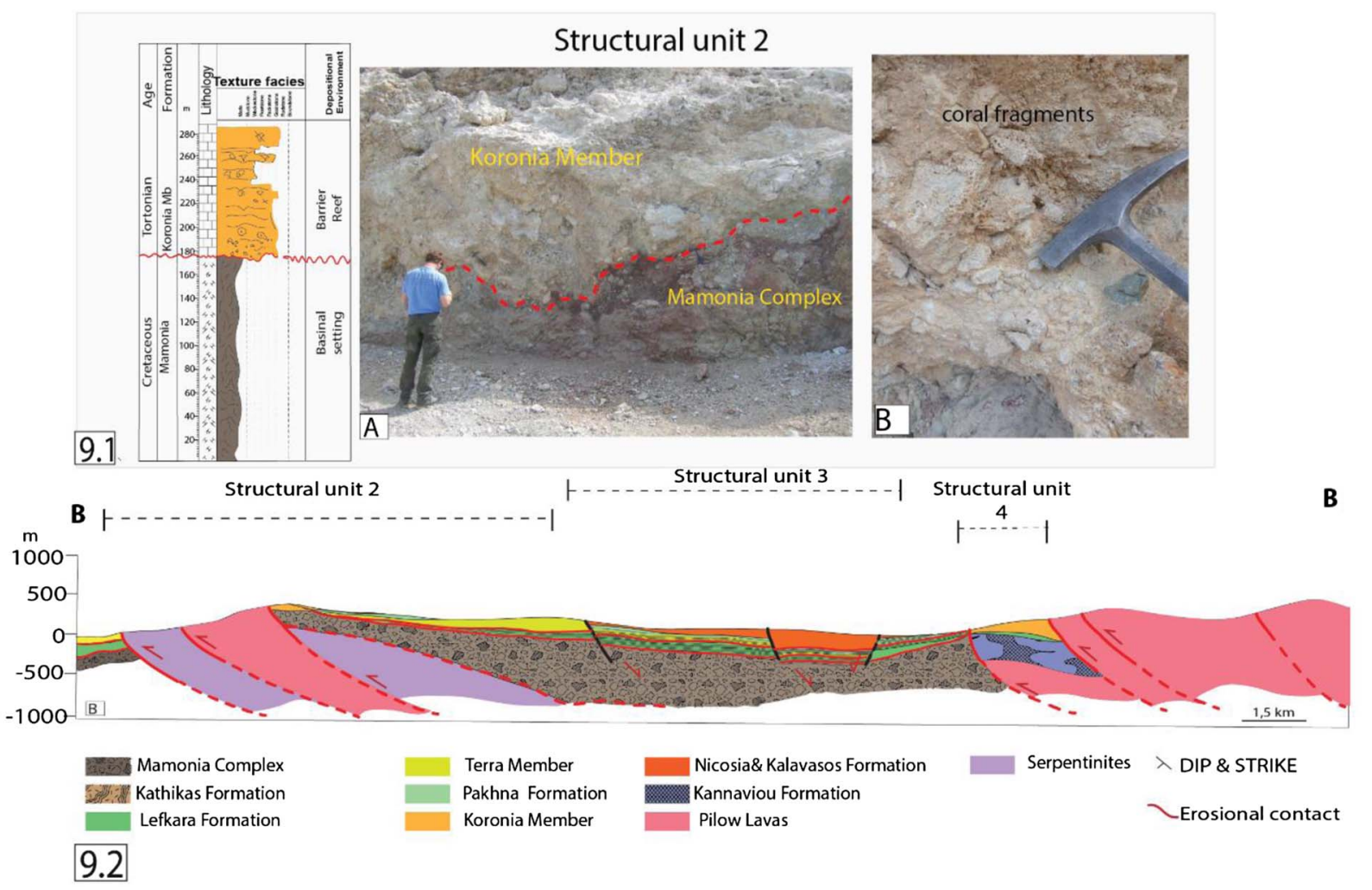

Fig. 9. [1] (A) Sedimentary log measured in the northern part of Polis Basin (i.e., Structural unit 2 - Akamas Peninsula; $35^{\circ} 1^{\prime} 36.80^{\prime \prime} \mathrm{N} ; 32^{\circ} 19^{\prime} 39.60^{\prime \prime} \mathrm{E}$ ); (B) Photograph showing the contact between the Koronia Member and the Mesozoic sediments); [2] SW-NE cross-section through the northern part of Polis Basin from Akamas Peninsula to the Pelathousa village (see the location on the map Fig. 4).

\section{Middle Miocene}

Reef front facies (Fa 2B) evolves into a 20 m-thick unit of open shelf deposits (Fa 3A; Fig. 6.2A). Open shelf deposits (Fa 3A) continue up to $280 \mathrm{~m}$ (Fig. 8.1A). Biostratigraphy results have shown that these sediments persist from the Langhian until the Tortonian and correspond to the Pakhna Formation. In the Pegeia region, these chalks are intercalated by reworked material of early Miocene age (Eaton and Robertson, 1993).

\section{Structural unit 2 (Akamas Peninsula)}

Located in the north-western part of Polis Basin, the Akamas Peninsula (Fig. 4) corresponds to a serpentinite belt which is found on top Mamonia Complex through a series of thrusts (Figs. 4 and 9.2; Monnet, 2005).

\section{Cretaceous}

The allochthonous rocks of the Mamonia Complex are characterized by volcanic breccias (Loutra tis Aphroditis Formation) sandstones (Vlampouros Formation and Akamas Sandstones) intercalated with pink calcilutites and radiolarian mudstones (Episkopi Formation; Fig. 4).

\section{Miocene}

On top of the grey Mesozoic sediments, reef limestones (Fa 2A) were identified (Fig. 9). The contact between the Upper Cretaceous unit and the Miocene reefs is marked by an erosional surface (Fig. 9). The reefs are $60 \mathrm{~m}$ thick and are mainly composed of boundstone intervals with corals (i.e., Porites sp.), and red algae (Fig. 9.1).

To the northern part of Polis Basin $\left(35^{\circ} 1^{\prime} 36.80^{\prime \prime} \mathrm{N}\right.$; $\left.32^{\circ} 19^{\prime} 39.60^{\prime \prime} \mathrm{E}\right)$, it has been noticed that the base of the reefs $(0-10 \mathrm{~m})$ consists of red algae fragments, corals, bioturbation and greyish beds of clay. Above this unit, irregular wavy poritid sheets are alternated with thin marl to packstone beds which could correspond to the Koronia $\mathrm{Mb}$ (Follows, 1992).

\section{Structural unit 3 (Polis Graben)}

In the "Polis Graben," Pliocene shallow marine (Payne and Robertson, 1995), as well as Quaternary continental deposits are exposed (Poole and Robertson, 1991, 1998, 2000). Hence, to examine the transition from Pliocene to Miocene units a 260-m deep borehole 1980/076 has been investigated (Figs. 4, 8.2A and 8.4).

\section{Miocene}

The deepest unit in the borehole corresponds open shelf deposits (Fa 3A) of Miocene age (Fig. 8.2A). The presence of Cyclicargolithus floridanus in the chalky limestone indicates a middle Miocene or older age (NN7a or older). Because some early Miocene age material is reworked, a younger age (middle Miocene) is preferred. 


\section{Messinian}

The transition from the Pakhna to Kalavasos formations (Fig. 8.2A and B) is found at $220 \mathrm{~m}$ below ground level (bgl), where whitish marly chalks pass to the thinly laminated gypsum (Fig. 8.2B). The Messinian is presented by $50 \mathrm{~m}$ of gypsum that are found between $150-220 \mathrm{~m}$ bgl. Although the description of the borehole is only brief, outcrop evidence found in the center of the basin, reveal that the Kalavasos Formation is represented by parallellaminated (Marmara) gypsum and massive fine-grained (alabaster) gypsum.

\section{Pliocene}

At $135-150 \mathrm{~m}$ bgl, a set of thinly bedded limestones with allochthonous pebbles marks the end of the MSC. These are succeeded by $130 \mathrm{~m}$ of grey marl with bivalves which indicate a shallow marine restricted environment (Fig. 8.2A).

\section{Structural unit 4 (Pelathousa-Peristerona)}

The eastern flank of the Polis Basin is referred to as Pelathousa-Peristerona block (Fig. 4) and is located $10 \mathrm{~km}$ to the east of the Akamas Peninsula (Fig. 4). Geological observations have shown that Troodos Ophiolites vanish towards the west (Figs. 4 and 8) whereas late Miocene reefs are exposed and rest on top of the volcaniclastic sediments of Kanaviou Formation (Figs. 4 and 8.4).

\section{Paleogene}

The Paleogene is not exposed, but field observations from the eastern flank of the basin allowed us to predict that this unit is composed of chalk alternated with cherts indicating a deep marine setting ( $\mathrm{Fa} 5 \mathrm{~B}$ and $\mathrm{Fa} 5 \mathrm{C})$.

\section{Miocene}

The lower part of the Miocene interval is investigated near Evretou dam (Figs. 8.3A and 8.4; $34^{\circ} 58^{\prime} 36.30^{\prime \prime} \mathrm{N}$, $32^{\circ} 28^{\prime} 24.60^{\prime \prime} \mathrm{E}$ ). It is composed of alternating highly bioturbated bioclastic sand shoal deposits (Fig. 8.3A). The alternation of high energy and low energy facies might correspond to small cycles that indicate flooding and shallowing of the region. Based on the presence of Cyclicargolithus floridanus (NN7a or older) and the absence of late Miocene assemblage we propose that these layers represent a Serravallian sequence.

Moving upwards in the sequence, we observed that the Miocene unit is composed of massive reefal limestones (Fa $2 \mathrm{~A}$ and $2 \mathrm{~B}$ ) which are characterized by thick $(3-5 \mathrm{~m})$ alternated, porous rudstone to grainstones (Figs. 8.3A, C and 8.4). Based on the results of radiogenic strontium isotopic analyses, Blanpied (2017) has shown that the exposed outcrop refers to late Miocene reefs.

\subsubsection{Limassol Basin}

Located in southern Cyprus, the Limassol Basin is bounded by the Yerasa Fault System (YFS), the Limassol Forest Block and the Troodos Ophiolites to the north (Fig. 4). The Yerasa Fault System is an early to middle Miocene group of faults (Kinnaird, 2008). The southern boundary of the Limassol Basin is located offshore Cyprus and is marked by the Akrotiri High which is now buried under the Pliocene sediments (Fig. 4). The Akrotiri High is trending in the same direction with the Yerasa Fault System and has been described as a thrust system controlled by a basement high (McCallum et al., 1993). To the west, the Limassol Basin is separated from Polis Basin by a transverse zone which extends along the Xeropotamos River (Fig. 4).

\section{Stratigraphic architecture of Limassol Basin}

The south-western margin of the Limassol Basin extends from the Paramali village up to the Petra tou Romiou (Fig. 4) where white chalks (referred to as Lefkara Formation) overlie brownish siliciclastic and volcanogenic sediments (referred to as Mamonia Complex). The basinal deposits of Paleogene age, in turn, are covered by rudstone breccias with occasional coral fragments (Fig. 10A). Although no contact has been found between the Paleogene and the Miocene formations, we assume that this abrupt change in the lithology is also marked by a sharp erosional surface.

Based on the composite logs constructed for the southern and the northern part of the Limassol Basin for the Miocene sequence six stratigraphic sequences have been recognized, (Figs. 10B and C). The base of each cycle corresponds to either an erosional surface or the transition of very shallow facies ( $\mathrm{Fa} \mathrm{2}$, i.e., coral reefs) into slope deposits (turbiditic deposits; Fa 4). In particular, the first sequence is only present along the southern coast of Cyprus and is represented by shoal deposits. To the north (Koilani composite log) and to the east this sequence is marked by an erosional surface on top of the deep marine sediments of the Lefkara Formation (Fig. 10C).

The base of the second sequence is found in the Paramali section is topped by open-shelf deposits (Fa 3A), whereas in the Koilani section, by peritidal deposits. Further up in the Paramali section, this cycle is divided into three sub-cycles. These sub-cycles represent deepening and shallowing events, with the alternation of open-shelf (Fa 3A) and reefal deposits (Fa 2A). Mainly to the south, the base of sub-cycles 1a, 1b, and 1c are marked at the top of the coral reef facies and represent the transition from barrier reef setting to open-shelf and deeper environments. In the Koilani section, the elementary cycles are absent, and shoal sands (Fa 1B) are succeeded by open-shelf (Fa 3A) deposits (Fig. 10C). The Maximum Flooding Surface (MFS) in both sections are marked by thin, chalky intervals, which coarsen upwards and end with coral reefs to the south and bioclastic sands to the north and the east. To the south, these cycles account for $110 \mathrm{~m}$ thickness of shallow carbonates, whereas to the north and the east there are only 50 and $60 \mathrm{~m}$, respectively (Fig. 10B).

The initiation of the third sequence in the southern part of the Limassol Basin is recorded by the transition of shallow marine facies (Fa 3) into slope and deep marine sediments ( $\mathrm{Fa} 4$ and $\mathrm{Fa} 5$ ). This change in the depositional environment is well represented in the south (i.e., the Paramali section), where coral reefs (Fa 2A) are overlain by turbidites ( $\mathrm{Fa} 4 \mathrm{~A})$ and pelagic sediments $(\mathrm{Fa} 5)$, which in turn are cut off by MTCs (Fa 4C). The same facies have been observed to the north and the east (Fig 10B) suggesting an overall drowning. Slope deposits, which are cut off by 


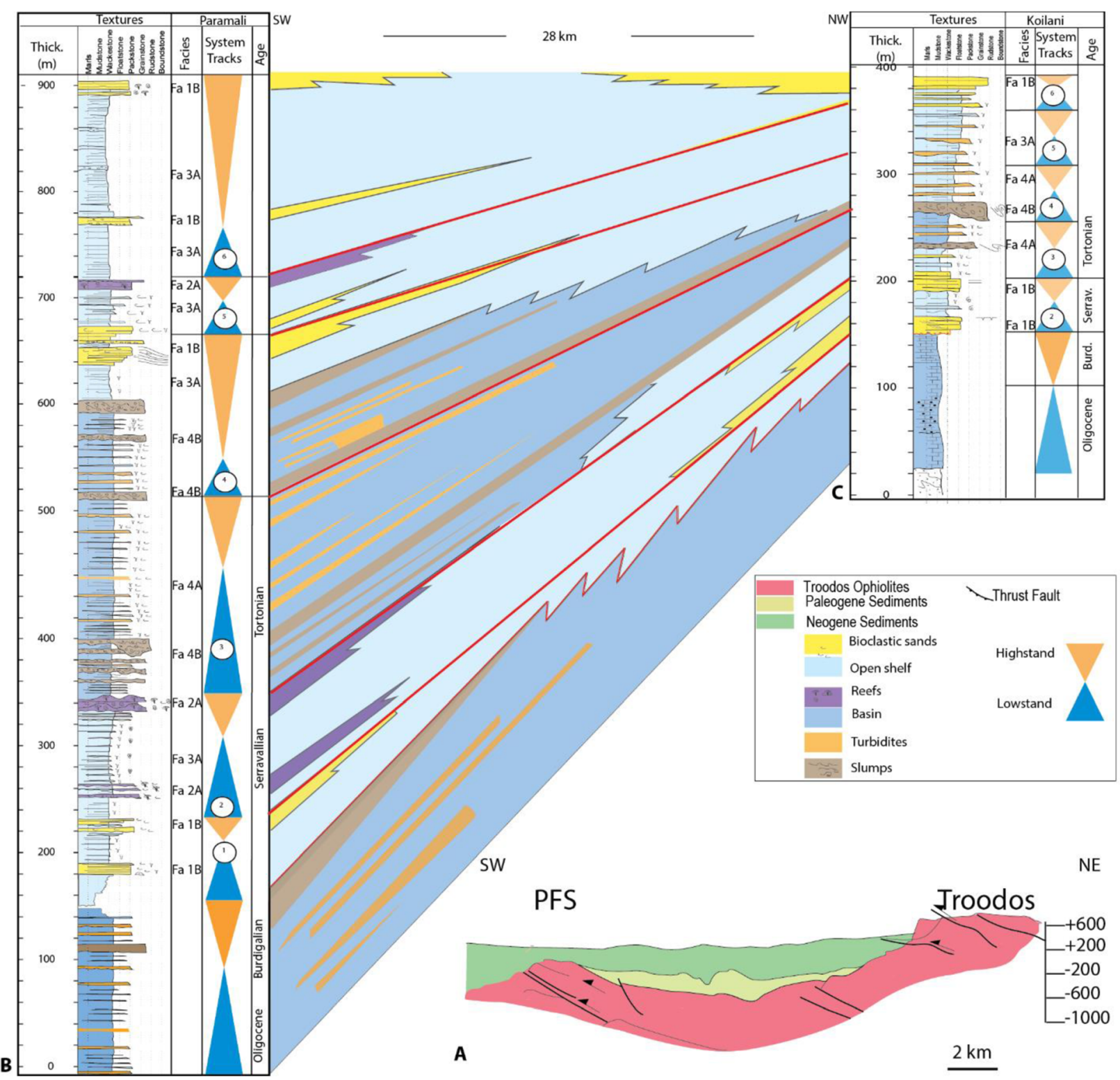

Fig. 10. (A) Synthetic cross-section of Limassol Basin. Synthesized measured and interpreted log sections of key exposures of the Miocene succession in Limassol Basin: (B) Paramali Composite sedimentary log and (C) Koilani composite sedimentary log. They represent an N-S transect to the western part of the Limassol Basin (see the location of the logs in Fig. 4)

MTCs, record the transgressive systems tract, whereas the MFS is marked by the transition to a deeper setting. Regarding the thickness, this cycle accounts for $180 \mathrm{~m}$ of sediments to the south, whereas the northern and eastern parts have 40 and $50 \mathrm{~m}$, respectively, indicating a migration of the depocenter further to the south. The top of this sequence is marked by an erosional surface below a remarkable MTCs (Fig. 10B). Further deepening was recorded in the fourth sequence which to the north is characterized only by deformed micritic carbonates.

The following highstand systems tract is represented by the transition of slope to open-shelf deposits (Fa 3A), which progressively, evolves, into bioclastic sands. To the north and east, the slope deposits (i.e., MTCs) pass into open shelf (Fa 3A) and relatively shallower sediments. Sea-level fall and/or uplift can explain the progressive shallowing of the basin to the south. In this case, the highstand systems tract and normal regression evolved as a forced regression. The continuous deposition of shallow marine sediments observed to the north and east excludes this hypothesis.

The base of the fifth sequence corresponds to another transgressive surface, above the bioclastic sand to the south, and below the first turbiditic interval in the northern and eastern parts of the basin. In particular, to the south, this surface records a further deepening of the area and deposition of shallow marine sediments. To the north and east, this cycle is characterized by slope deposits (Fa 4). The end of this cycle is recorded by the formation of coral reef 
to the south, and bioclastic sands bars (Fa 1B) to the north and east (Figs. 10B and C).

The sixth sequence is marked by drowning of the coral reefs and the bioclastic sands to the south and the northeast respectively. It seems that the entire basin was filled up with shallow-marine/open-shelf deposits. The following highstand, recorded in the basin by the transition of open-shelf deposits (Fa 3A) into bioclastic bars with some patches of coral reef to the south $(\mathrm{Fa} 2 \mathrm{~A})$, and another bar of bioclastic sands ( $\mathrm{Fa} 1 \mathrm{~B})$ to the north and east (Figs. 10B and $\mathrm{C}$ ). The bioclastic sands (Fa 1B) to the south prograde towards the NE whereas those that are deposited to the eastern part of the basin prograde towards the NW. The thickness of this cycle varies from the south to the north. In particular, to the south, these sediments are $180 \mathrm{~m}$ thick, whereas the northern and the eastern parts account for only $60 \mathrm{~m}$ of sediments.

\section{Discussion}

\subsection{Reconstruction of Polis Basin since the Cretaceous}

New offshore studies west of the Polis Basin, based on seismics and fault plane solution indicate a strike-slip structure termed the Paphos Transform Fault (Papazachos and Papaioannou, 1999). These results are in contrast with the proposed models by Payne and Robertson (1995, 2000), thus prompting a re-evaluation and the proposal of a new conceptual model that explains the structures and the deformation encountered during the field campaigns in Cyprus.

The early phase of sedimentation in the Polis Basin occurred in the late Maastrichtian (Kähler and Stow, 1998) and is marked by pelagic sediments of the Lefkara Formation. These sediments are found directly on top of the Mesozoic (Fig. 11A). It is assumed that the Polis Basin was part of a deep basin (Fig. 11A) with the nearest land being further north and represented by the Taurus Mountains of southern Turkey (Robertson and Fleet, 1976; Robertson et al., 1991, 2012).

From the late Oligocene to the early Miocene, the Eastern Mediterranean experienced a regional uplift coeval to a long-lived lowstand (Haq et al., 1988) which might be also linked to the collision of the African and Eurasian plates (Dercourt et al., 1986; Robertson, 1998a, b; Jolivet and Faccenna, 2000; Dargahi et al., 2010). The inferred uplift in the Polis area is identified by blind thrusts and karstification on top of the Lefkara Formation that is exposed locally, near the Kathikas village (Fig. 11B). It seems that the Upper Cretaceous thrust activity at the Troodos Ophiolites propagated further to the south-west near Kathikas village and thus a new basin was formed (Fig. 11B).

During its early stages, the Polis Basin was characterized by reefal $(\mathrm{Fa} 2 \mathrm{~A})$ and reef front $(\mathrm{Fa} 2 \mathrm{~B})$ sediments that evolved into open shelf deposits (Fa 3A; Fig. 11B). Crosssections in the basin portray the accurate pattern of the early Miocene reefs which in turn reflects the topography of western Cyprus during that time (Fig. 4). These reefs (i.e., Terra Member) were mainly formed on the basin margins. Reworked material from Cretaceous (Kathikas $\mathrm{Fm}$ ) and Oligocene (Lefkara Fm) formations are found in the early Miocene sediments depicting a tectonically active period. The reef front facies were identified in an NW-SE trending zone parallel to the linear trend of the reef patches (Fig. 11B). Although there are no signs for the direction of the paleoslope, the borehole data suggest that the highenergy reef front sediments evolved into low energy shelf deposits in the center of the Polis Graben. During the Langhian, a global sea-level rise occurred (Haq et al., 1988; Hawie et al., 2013). In the Polis Basin, the bioclastic shallow marine sediments with reef front and reefal facies were succeeded by open shelf deposits (Fig. 11C). Microscale analysis revealed that the middle Miocene sediments were floored with reworked early Miocene material (i.e., C. fenestratus, Z. bijugatus, and S. dissimilis).

Sea-level rise alone cannot explain the deepening of this region, and it is unlikely that no tectonic activity was involved in the sedimentary evolution of the basin during this period. Payne and Robertson (2000), suggest that the dominant deformation mechanism was associated with an extensional regime expressed by large normal faults which bound of the basin flanks. This period of extension may be associated with slab rollback along the northward subduction of the African plate during the Miocene. Indeed, during our field studies, we observed east of the Kathikas high/plateau NNW-SSE normal faults cutting Pakhna sediments (Fig. 4). These faults have been interpreted by Monnet (2005) as pronounced escarpments associated with gravitational forces and not as deep structures.

A possible mechanism for the subsidence of the basin can be the tilting of its basement which might have occurred due to the SW propagation of the thrust belt and the contemporaneous uplift of the southern slopes of the Troodos Mountains. As a consequence, some gravitational faults were created in the center of the basin which was covered by relatively deeper sediments. In contrast, the north-eastern flank of the basin (near the slopes of Troodos Mountains) was covered by sand shoal deposits which were prograding to the south-west (Fig. 11C).

Nevertheless, the local accommodation space in piggyback basins can be created by out of phase thrust activity and the subsequent migration of the depocenter (Zoetemeijer et al., 1993; Chanvry et al., 2018). Usually, the depocenters in piggyback basins migrate towards to the foredeep as a result of the propagation of the thrust belt. Out of phase thrusting (back thrust) can lead to the migration of the depocenter towards the inner land. Thus, further investigation should be undertaken in order to examine the mechanisms of subsidence during this period.

During the late Tortonian, reefs (Koronia Member) colonized the eastern and the western flanks of the Basin (Fig. 11D). The development of the Koronia Member should be connected with a late Miocene thrust activity which propagated towards the SW (Pafos Thrust) and/or the sea-level drop before the MSC (Haq et al., 1988). This thrust activity is thought to be ceased during this period since the thrust faults in the Pelathousa Region are sealed by the Koronia Member (Fig. 11D). 

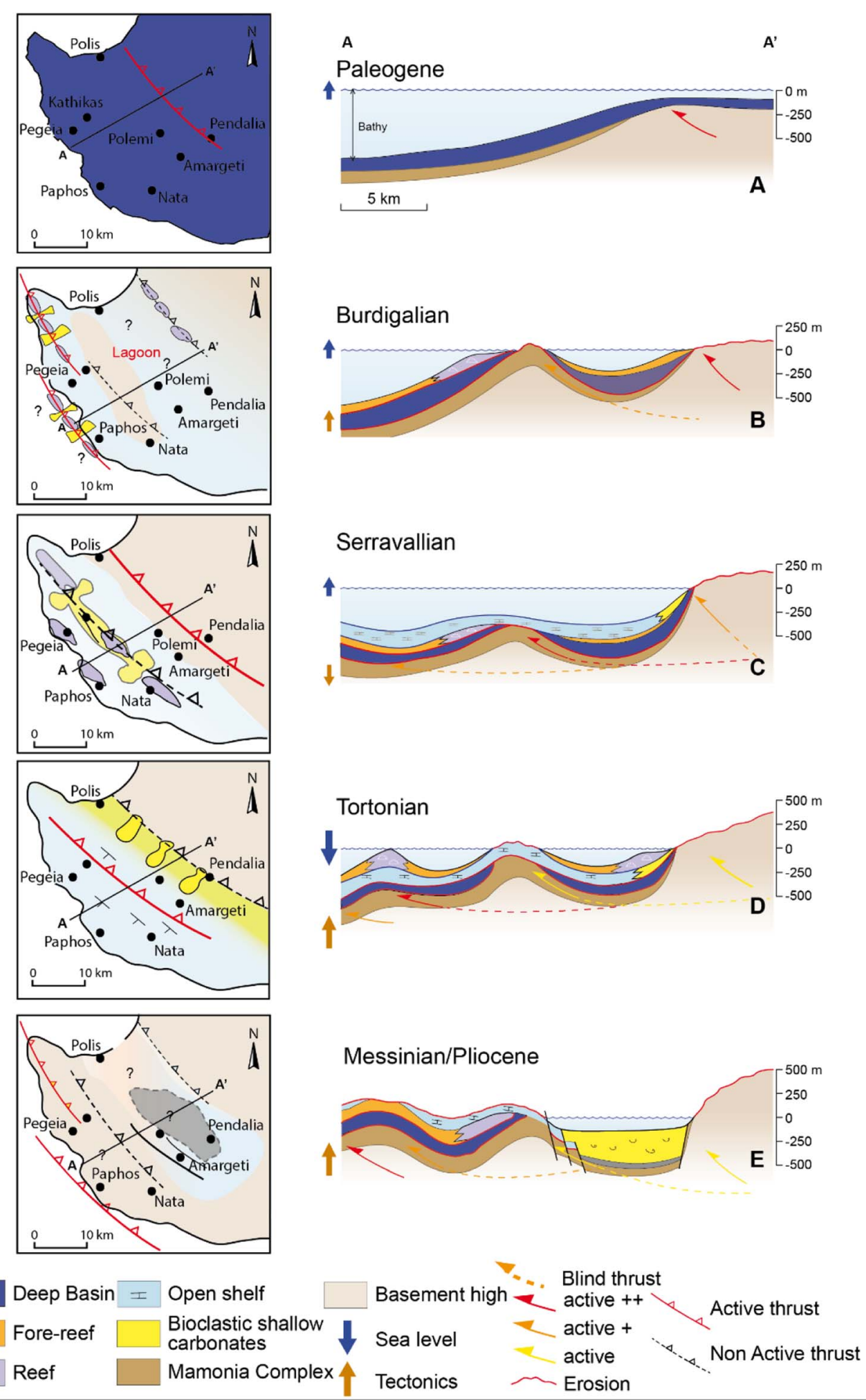

Fig. 11. Synthesized scheme and paleoenvironmental maps illustrating the evolution of the Polis Basin from the Late Cretaceous until the Pliocene.

In the eastern flank, no extensional traces prior to Pleistocene have been identified. Nevertheless, the presence of Messinian evaporites on top of the neritic carbonates of Pakhna Formation as well as the thick sequence $(150 \mathrm{~m})$ of Pliocene marine sediments in the center of the basin (Payne and Robertson, 1995), led us to propose the formation of a N-S asymmetrical depression during the post Tortonian period (Fig. 8.4). This NW-SE depression formed 
within the present-day Polis valley (Structural unit 3; Fig. 8.4; Follows, 1992; Payne and Robertson, 1995) and was controlled by normal gravitational faults that created during the tilting of the basement due to the propagation of the thrust belt (Fig. 11E).

Field observations have shown that the Kalavasos Formation (Messinian evaporites) is absent from the northern part of the Polis Graben (Kinnaird, 2008). In addition, at the eastern and the western flanks of the graben, the Miocene carbonates are directly overlain by the Pleistocene deposits without any evidence of Messinian or Pliocene sedimentation (Figs. 4 and 11E). In contrast, the southern part of the graben in the center of the basin was deep enough to be filled with the Messinian evaporites as indicated by the presence of outcropping laminated gypsiferous marls and gypsum in the boreholes (Fig. 8.2).

During the Pliocene, the deposition of evaporites was followed by the inundation of the basin with sea waters (Robertson, 1998a; Bowman, 2011; Hawie et al., 2013; Gorini et al., 2015). The increased thickness of the Nicosia Formation towards the center of the Polis Graben (Figs. 8.4 and 9.1) and its absence from the Pegeia region and Akamas Peninsula reflects the infill of the existing basin (Fig. 4).

The deposition of shallow water calcarenites within the Polis Graben during the late Pliocene and early Pleistocene combined with the non-deposition elsewhere reflects the first stages of the general uplift of Cyprus (Payne and Robertson, 1995; Kinnaird, 2008). The continuous shallowing during this time can be linked with the southward propagation of the thrust activity and thus the migration of the depocenter towards the foredeep. It is assumed that the youngest thrust-sheets are located offshore and are the equivalent of the Cyprus Arc.

\subsection{Reconstruction of Limassol Basin}

Based on biostratigraphic results and field observations, it is suggested that the Limassol Basin was created during the early to middle Miocene (Burdigalian - Langhian). During this time, compression and propagation of the thrust belt to the south, resulted in the initiation of several thrusts, in an NW-SE direction (i.e., the Yerasa and Akrotiri fault systems), bounding the Limassol Basin (Fig. 4). The sedimentary record shows an unconformity to the north of the basin, where basinal deposits (contourites) are directly overlain by intertidal sediments (Figs. 12A and B). This abrupt shallowing of the region marks an episode of uplift that on a regional scale, might be attributed to the position of Cyprus, in the complex zone of convergence between Africa and Eurasia (Robertson and Woodcock, 1986; Eaton and Robertson 1993). To the south, the basin was colonized by small, mounded bioherms, surrounded by reef-talus and shallow-water carbonates whereas to the north by bioclastic shoals (Figs. 12B and C; Stow et al., 1995). It is assumed that the reefs in the southern margin of the basin colonized the relief topography that was created by a blind thrust (referred to as Akrotiri High or Akrotiri Fault System; Fig. 4).

During the Tortonian, the Limassol Basin experienced significant subsidence and the Miocene reefs to the south as well as the bioclastic sands to the north were covered by slope to deep marine sediments (Fig. 12D). Progressive thickening of the Tortonian sediments, from north to south, suggests a southward migration of the depocenter (Fig. 12D). In particular, to the south, $500 \mathrm{~m}$ of slope to basinal deposits have been measured, whereas the northern part of the basin accounts for only $80 \mathrm{~m}$ of sediments. The subsidence of the basin can be explained by the thrust activity at the southern slopes of the Troodos Mountains. The early Miocene Yerasa Thrust System was still active during the Tortonian and as a basement thrust caused the displacement of the Troodos Ophiolites to the south and thus the thickening/stacking of the crust. Consequently, the northern part of the Limassol Basin was out of isostatic equilibrium and must have partially sunk. Therefore, the southern part of the basin which was underlined by relatively thin crust compared to the north, subsided, allowing further subsidence of the overlain sedimentary basin.

On the flanks of the basin, MTCs have been identified. Previous works suggest that the MTCs are oriented in eastsoutheast (Farrell and Eaton, 1987; Eaton and Robertson, 1993; Kinnaird, 2008), or in the east-west direction (Lord et al., 2009). During the present study, measurements along the Limassol-Pafos highway to the south $\left(34^{\circ} 41^{\prime} 12.51^{\prime \prime} \mathrm{N}\right.$, $32^{\circ} 41^{\prime} 24.64^{\prime \prime} \mathrm{E}$ ), and near Dora village to the north $\left(34^{\circ} 45^{\prime} 14.42^{\prime \prime} \mathrm{N}, 32^{\circ} 41^{\prime} 19.12^{\prime \prime} \mathrm{E}\right)$, agree with Eaton's (1987) results (Fig. 4). However, it is unlikely that the slope was dipping uniformly away from the Troodos Ophiolites, since Eaton and Robertson, (1993) noted two exceptions near Agia Fila and Happy Valley, depicting a palaeoslope direction towards the north (Fig. 4). Thus the direction of the slope must have also been controlled by a northward dipping structure probably located south of Cyprus. This structure could correspond to the Pafos Thrust (Monnet, 2005). Since the MTCs are the result of intense seismic activity (e.g., earthquakes) (Alves, 2015; Arfai et al., 2016; Guan et al., 2016) it is proposed that, during the Tortonian, the thrust belt propagated further to the south resulting in the initiation of the Pafos Thrust (Fig. 12E).

Before the Messinian, the Limassol Basin was filled with shallow marine sediments (Fig. 12E) and therefore the basin experienced an uplift probably associated with the southward propagation of the thrust belt. Along the eastern margin of the basin, bioclastic sand shoals began to prograde towards the NW, whereas to the south the bioclastic sands were prograding towards the NE (Figs. 10B and C).

\subsection{A new model for the Cenozoic tectonostratigraphic evolution of Cyprus}

Using the field data presented in this contribution, and recently published geophysical data (Welford et al., 2015; Reiche et al., 2016; Granot, 2016) a new paradigm for the tectonostratigraphic evolution of southern Cyprus since the Late Cretaceous can be proposed.

A northward-dipping subduction zone is thought to have been initiated during the Turonian, with the opposing movement of the Afro-Arabian and Eurasian plates, resulting in the formation and obduction of the Troodos Ophiolites (Bowman, 2011; Montadert et al., 2014). After their obduction (Campanian until the Maastrichtian), the 


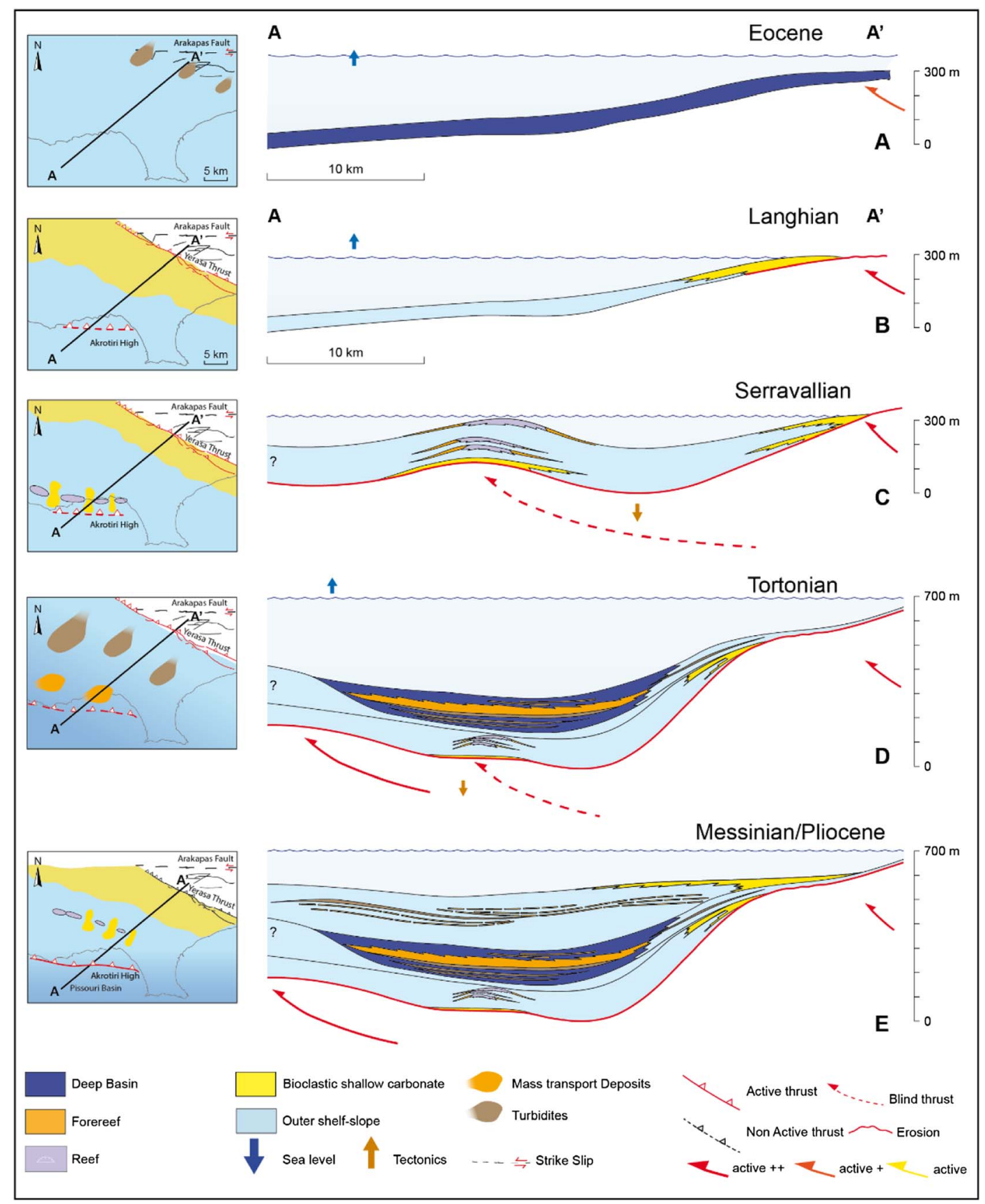

Fig. 12. Synthesized scheme and paleoenvironmental maps illustrating the evolution of the Limassol Basin during the Miocene.

ophiolites juxtaposed with the Mamonia Complex (Fig. 13A; Bailey et al., 2000). At that time, westerly directed thrusting, at the slope of Troodos Mountains, and sinistral transpression along the Mamonia Suture Zone took place (Figs. 1 and 2). The transpressional movement is recognized by a transverse fault zone along the Xeropotamos River (Fig. 4). This fault zone defines the limit of the Mamonia Complex onshore Cyprus and has been interpreted as the prolongation of the Continental Oceanic Boundary (COB), that is identified offshore Cyprus (Figs. 1, 2 and 4; Granot, 2016).
From the Maastrichtian until the late Eocene, the Mediterranean was under deep marine conditions, with no evidence of ongoing plate convergence (Fig. 13B; Robertson et al., 2012). During the late Eocene, the convergent plate boundary migrated southwards, following the collision of the Keryneia Range with the Troodos Ophiolites (Fig. 13B; Robertson and Woodcock, 1986). The collision and the southward propagation of the thrust activity resulted in the submergence of the Keryneia Range and the subsequent development of an extensive submarine fan system (Robertson and Woodcock, 1986). 

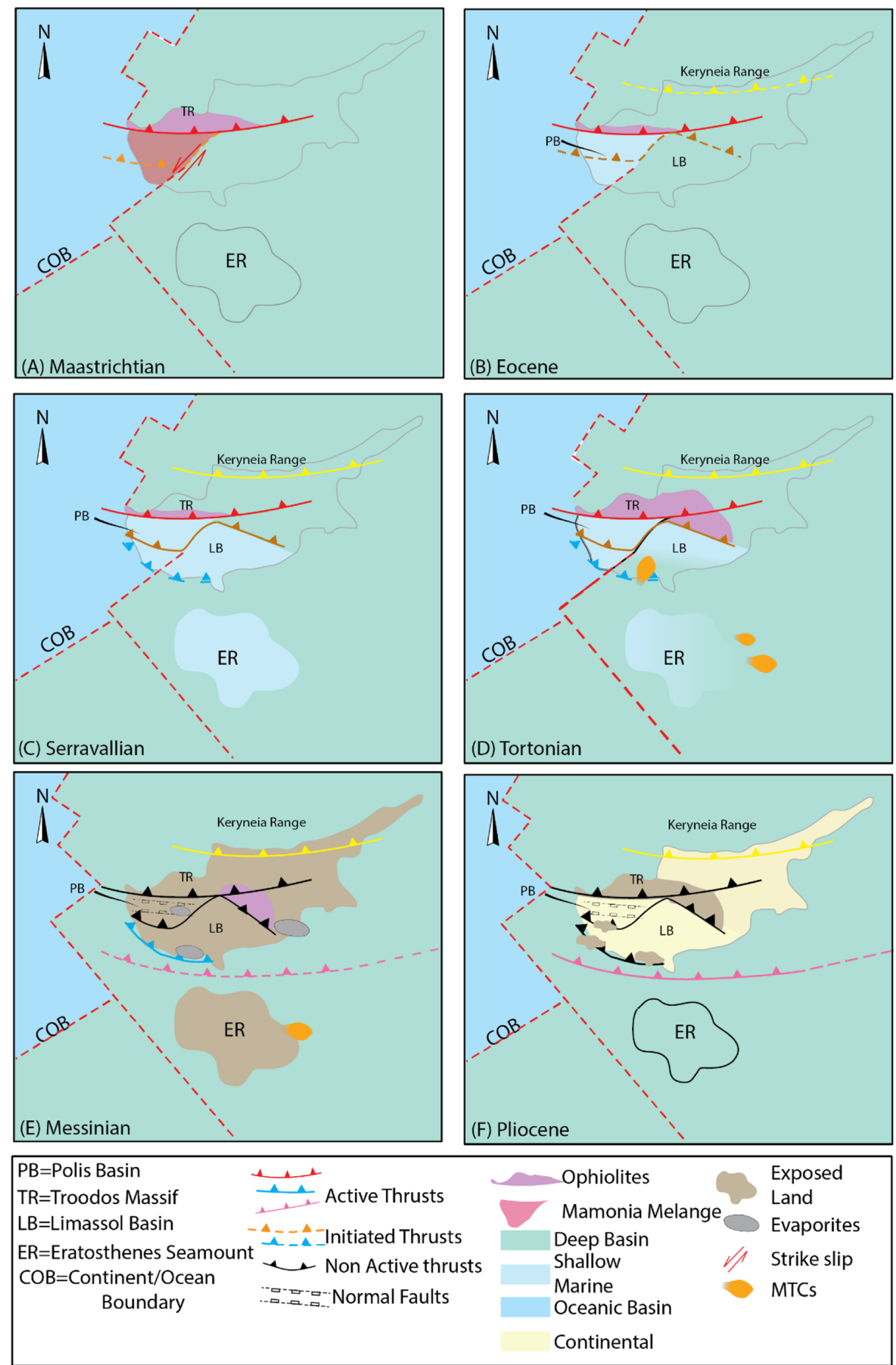

Fig. 13. Paleoreconstructions showing the evolution of southern Cyprus based on the forward propagation model. 
In southern Cyprus, the sedimentation style shows a diachroneity between the Limassol and Polis basins, suggesting a differential uplift. For instance, the southern margin of Polis Basin was controlled by thrust faults, where small reefs formed (Terra Member), suggesting southward propagation of the thrusts from the southern slopes of the Troodos towards the Kathikas village (Fig. 13B). On the other hand, in the Limassol Basin, a relatively deeper marine environment prevailed until the early Miocene (Fig. 13B). During the following period (Langhian Serravallian), the Limassol Basin was under a shallow marine setting (Fig. 13C). Eaton and Robertson (1993) suggested that the uplifted area was controlled by southward verging thrusts (YFS) that are visible on the slopes of the Troodos Mountains.

Evidence of Late Miocene compressional deformation is documented in both basins. In the western flank of Polis Basin, an erosional surface between Late Miocene reefs and the Cretaceous pillow lavas depicts an early/Late Miocene movement along a thrust fault. In the eastern flank of the Polis Basin, the Pelathousa-Peristerona thrust was active as evidenced by the deposition of the Koronia Member reefs which are tilted towards the east and are in direct contact with the Campanian sediments (Fig. 13D). On the contrary, the Limassol Basin suffered by significant subsidence and deep marine sediments deposited in the southern part of the basin (Fig. 13D).

The collision between Eratosthenes Seamount and Cyprus Arc during the latest stages of the Miocene (Robertson, 1998b; Papadimitriou et al., 2018) resulted in a progressive shallowing of the two Neogene basins (Fig 13E). During this time, pre-existing normal faults continued to control the central part of the Polis Basin, (Polis Graben) whereas, on its flanks, small patch reefs were developed (Fig. 11). In the Limassol Basin, the sedimentation was dominated by prograding bioclastic sands with some patch reefs in the eastern and the southern margins (Fig. 12D).

New Geophysical data that cover the northern part of the Levant Basin support that during the late Miocene compressional nature of the Latakia Ridge system changed to a sinistral strike-slip (Hall et al., 2005a, b). This change in the compressional regime between the two plates, may have resulted in the westward propagation of the $\mathrm{COB}$ (Fig. 1) explaining the eastward migration of the apparent deformation observed onshore Cyprus (Fig. 13E).

The Plio-Pleistocene time is envisaged as a period of tectonic uplift (Sage and Letouzey, 1990; Orszag-Sperber et al., 1989; Eaton and Robertson, 1993; Robertson, 1998b; Kinnaird and Robertson, 2012). Evidence of this uplift has been found within the Polis and Limassol basins (Fig. 13F). In particular, late Pliocene and early Pleistocene shallow water calcarenites were observed in the center of the Polis Basin (i.e., Polis Graben) whereas its marginal areas were subaerially exposed (Fig. 13F; Payne and Robertson, 1995; Kinnaird, 2008).

\subsection{Piggyback vs. flexural basins}

Both Limassol and Polis basins were formed under a compressive regime (Figs. 11-14). The transition from one basin to the other was previously defined by a slightly oblique ramp outcropping from the coastline to the southern slopes of the Troodos Mountains, through the Xeropotamos River (Fig. 4) trending in a north-south direction (Monnet, 2005).

Kähler and Stow, (1998) suggested that gradual uplift and an increase in sediment input from the northeast can explain this lateral change in depositional environment between the two basins. The question that arises from this statement is: What might be the cause of the progressive and differential uplift between the two basins?

A good explanation would be given due to the structured part of the Polis Basin substratum associated with the collision of the Mamonia Complex with the Troodos Ophiolites (Bailey et al., 2000; Lapierre et al., 2007). However, this hypothesis does not explain the diachroneity and the spatial distribution of Miocene thrusts alongside the Limassol and Polis basins (Figs. 14 and 15).

In the Polis Basin, the early Miocene thrust sheet extends from Mesogi to the Akamas Peninsula, whereas in the Limassol Basin, this thrust is referred to as Yerasa Fault System (Figs. 14 and 15). It is proposed that the two faults are connected through the transverse fault zone, across the Xeropotamos River (Fig. 4).

The Polis Basin is formed on top of the sedimentary cover of the Mamonia Complex (Fig. 14). In contrast, the Cenozoic sediments found in the Limassol Basin overly the rigid ophiolitic complex (Fig. 14). The nature of the substratum and the "subducting" crust between the two basins (oceanic in Polis and thin continental in Limassol) can explain the diachroneity of the thrusts as well as the differences in intensity of the deformation style between the two. As one of a series of piggyback basins, the Polis system must have been formed in association with upper crust, thin-skinned NW-SE thrusts, detached from their basement along a decollement horizon (Zoetemeijer et al., 1993; Muñoz et al., 2013). It is expected that the decollement level of such thrusts is within the weak sediments of the Mamonia Complex (Fig. 14). In contrast, $500 \mathrm{~m}$ of Tortonian series in the Limassol Basin implies the local emplacement of a substantial lithospheric load to generate such rates of flexural subsidence.

Hence, thin-skinned vs. thick-skinned tectonics can explain the eastward increase (from 50 to $500 \mathrm{~m}$ ) in the sedimentation, along the southern limits of the Polis and Limassol basins. The southward propagation of the thrust belt in both basins and the synchronization of the deformation is recorded by the Pafos Thrust (Fig. 15A). In the Polis Basin, the activity of this fault resulted in the uplift of the flanks and the subsequent tilting of the basement and thus the formation of Polis Graben. In contrast, in Limassol Basin, the initiation of Pafos Thrust is recorded by MTCs which cut the deep marine sediments. It has been postulated that the MTCs record also the collision of the Eratosthenes Carbonate platform with the Cyprus Arc (Papadimitriou et al., 2018).

A good analog of the Polis and Limassol basins would be the Graus-Tremp-Ainsa basins which are located in the southern Pyrenées (Chanvry et al., 2018). In particular, in the south Pyrenees, the easternmost basin (i.e., the Organya-Tremp-Ager sub-basins) is controlled by three 


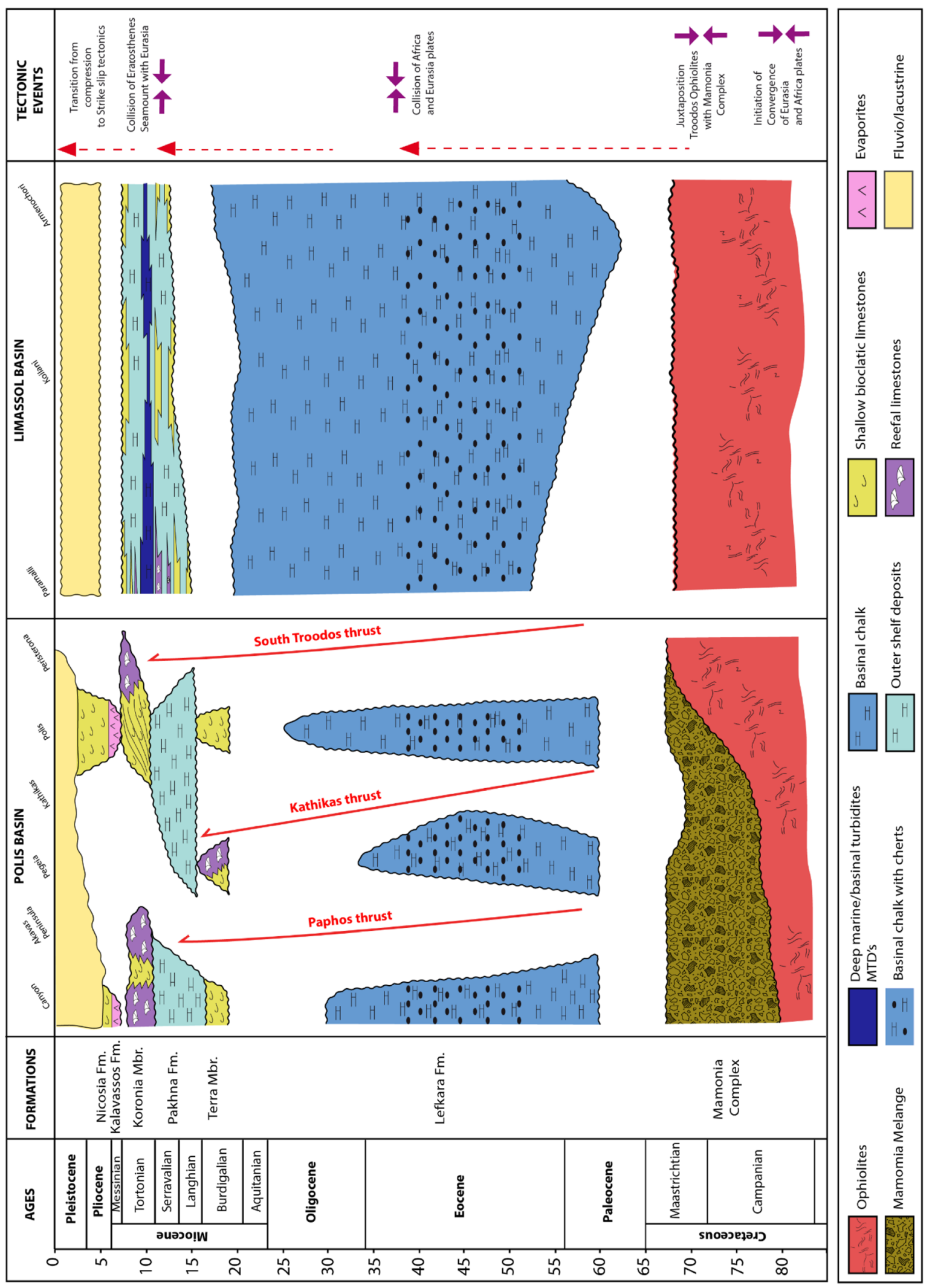

Fig. 14. Synthesized chronostratigraphic chart which shows the lithologies and the major hiatuses in Limassol and Polis basins with respect to the main geodynamics. 

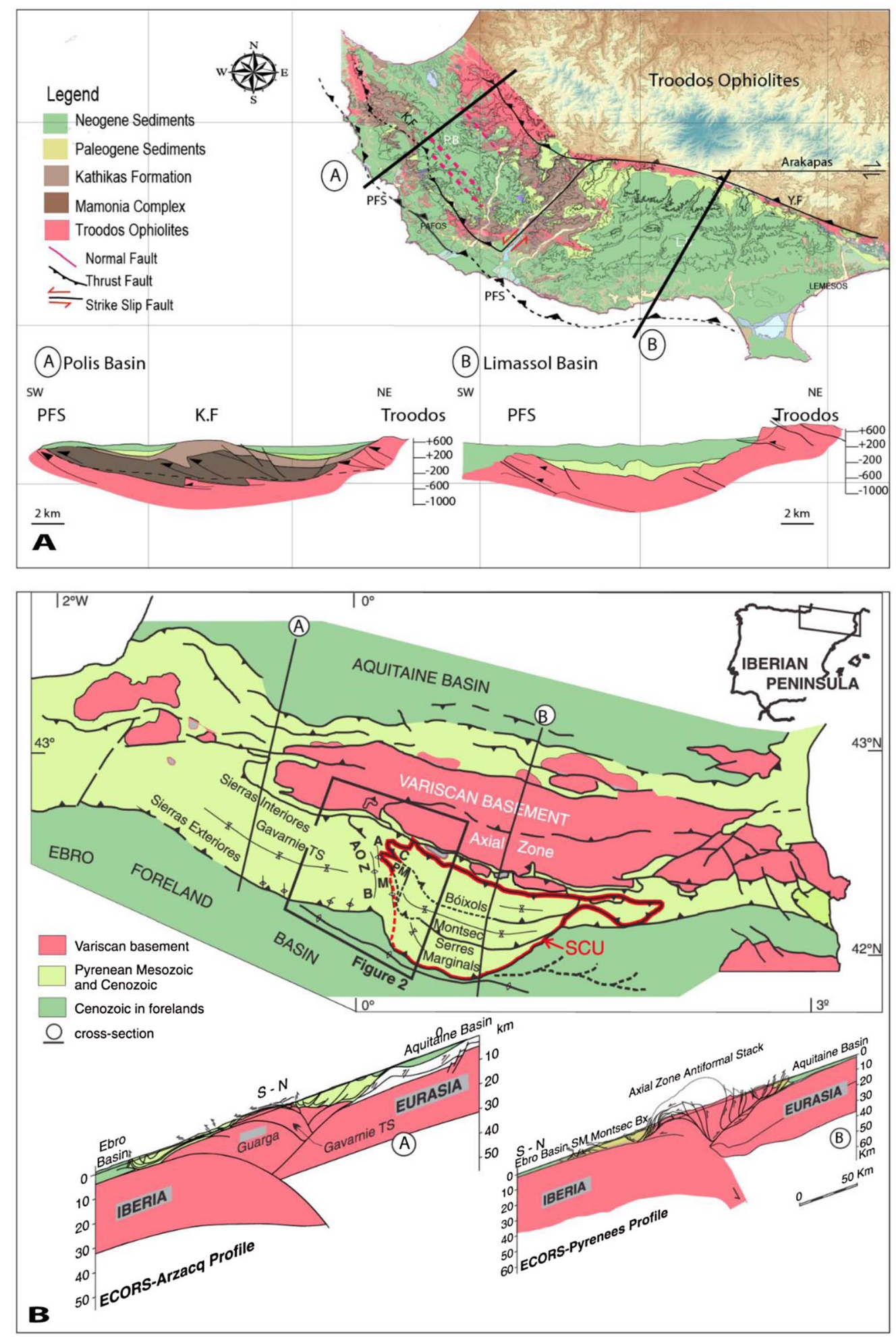

Fig. 15. [A] Geological map of southern Cyprus with the main structures that have been discussed during the present study; (A) Cross-section of Polis Basin; (B) Cross-section of Limassol Basin; CA - Cyprus Arc; PFS - Pafos Fault System; ATF - Arakapas Transform fault; PB - Polis Basin; LB - Limassol Basin; KF - Kathikas Thrust; [B] Sketch showing the main structural units of the central Pyrenees and the major anticlines of the Ainsa Oblique Zone at the western boundary of the major thrust in the central Pyrenees. Crustal cross-sections at both sides of the Ainsa Oblique Zone illustrate changes of the structural style along strike. AOZ - Ainsa Oblique Zone; A - Añisclo Anticline; B - Boltaña Anticline; M - Mediano Anticline; C - Cotiella; PM - Peña Montañesa; SCU - South Pyrenean Central Unit; Bx - Bóixols; SM - Serres Marginals (modified from Muñoz et al., 2013). 
thrusts creating a series of piggyback basins (the Bóixols, Montsec and Sierra Marginales) whereas to the west (Ainsa to Jaca basins), a flexural basin prevails; bounded by one thrust-front zone to the south (Fig. 15B; Chanvry et al., 2018; Muñoz et al., 2013). The two systems are separated by a lateral ramp (the Mediano structure, Fig. 15B) and have been set up during the initiation of the convergence between Iberia and Eurasian plates (Chanvry et al., 2018; Fillon et al., 2013; Muñoz et al., 2013). The partitioning of the basins in south Pyrenees can be explained by the different nature of the substratum below the Paleogene sediments in the two areas (Fig. 15B).

As it is shown in Fig. $15 \mathrm{~B}$ in the Axial Zone, the Mesozoic and Cenozoic sediments are floored by Triassic evaporites whereas to the west these evaporites are absent. South of the Axial Zone, the Mesozoic cover is detached along the Triassic evaporites forming the Bóixols, Montsec and Sierra Marginales thrust-sheets. In the western basins, the Mesozoic and Paleogene covers are coupled to the basement, and the basement thrusts are mostly imbricated (Fillon et al., 2013; Muñoz et al., 2013). Therefore the central zone was controlled by thin-skinned tectonics and the western part by thick-skinned. The thin-skinned system propagated and migrated both southward and westward in response to the non-orthogonal collision of Iberia with Europe during Paleogene mountain building. In contrast, to the west, the thrust system has been interpreted to be a longer-lived structure that initiated during the extensional tectonic regime in Middle Cretaceous time and inverted during the main episode of the Pyrenean collision (Fillon et al., 2013; Muñoz et al., 2013). The development of the basement thrust system caused regional subsidence along the south Pyrenean foreland margin which was subsequently halted by local uplift associated with the west-migrating thin-skinned thrust system (Chanvry et al., 2018; Fillon et al., 2013; Muñoz et al., 2013).

\section{Conclusion}

Based on fieldwork in southern Cyprus, and the review of previous works, a better understanding of the tectonostratigraphic evolution of Cyprus has been achieved. The results pertaining to the sedimentary filling and the structural evolution of two Neogene basins (Polis and Limassol) as follows:

- The Polis Basin is interpreted as a piggyback basin that is controlled by thin-skinned tectonics. This kinematic evolution of the thrust belt is localized by the weak sediments of the Mamonia Complex below the detached Cenozoic successions. The Polis piggyback basin has evolved from the interaction of four thrusts: (a) the Troodos thrust, (b) the Kathikas thrust, (c) the Pafos Thrust and (d) the Cyprus Arc.

- The geometry and thus the sedimentation in Limassol Basin was controlled by a main blind-front thrust to the south and an oblique ramp to the west. The forward propagation of the thrust belt is only related to crustal shortening which recorded the main geodynamics. The main thrusts that control the Limassol Basin are (a) the Yerasa Fault, (b) the Pafos Thrust and (c) the Cyprus Arc.

- The slightly oblique ramp (referred as a transversal zone along the Xeropotamos River) determines the transition between the shallow marine sediments deposited in Polis Basin and the slope to basinal setting observed in the Limassol Basin.

- The MTCs identified in the Limassol Basin are associated with an intense tectonic activity that occurred during the late Miocene. Similar MTCs, but with different scale have been identified to the eastern and the western sites of Eratosthenes Seamount offshore Cyprus.

- The integration of structural and sedimentological data to propose a reconstitution of the northern margin of the Cyprus Arc between Oligocene to late Miocene. The kinematic model that best matches all the observed data is that of the forward propagation model.

Acknowledgments. The authors would like to acknowledge the Ministry of Energy, Commerce, Industry and Tourism of the Republic of Cyprus as well as the Geological Survey Department of Cyprus. A very warm thank you to Dr. Zomenia Zomeni and Dr. Efthymios Tsolakis for their contribution and their help during the field studies onshore Cyprus.

\section{References}

Alves T.M. (2015) Submarine slide blocks and associated softsediment deformation in deep-water basins: A review, Mar. Pet. Geol. 67, 262-285. https://doi.org/10.1016/j.marpetgeo. 2015.05.010.

Arfai J., Lutz R., Franke D., Gaedicke C., Kley J. (2016) Masstransport deposits and reservoir quality of Upper Cretaceous Chalk within the German Central Graben, North Sea, Int. J. Earth Sci. 105, 3, 797-818. https://doi.org/10.1007/s00531015-1194-y.

Bailey W.R., Holdsworth R.E., Swarbrick R.E. (2000) Kinematic history of a reactivated oceanic suture: The Mamonia Complex Suture Zone, SW Cyprus, J. Geol. Soc. 157, 1107-1126. https://doi.org/10.1144/jgs.157.6.1107.

Blanpied C. (2017) Tertiary reefal carbonate in Cyprus: Absolute ages obtained by using strontium isotope stratigraphy (SIS) help refine the tectonostratigraphic calendar of the island, AAPG Europe Region Conference - Hydrocarbons in the Mediterranean: Revisiting Mature Plays and Understanding New and Emerging Ideas, 18-19 January, Lanarca, Cyprus.

BouDagher-Fadel M., Lord A. (2006) Illusory stratigraphy decoded by Oligocene-Miocene autochthonous and allochthonous foraminifera in the Terra Member, Pakhna Formation (Cyprus), Esuclacuk 3, 3, 217-228.

Bowman S.A. (2011) Regional seismic interpretation of the hydrocarbon prospectivity of offshore Syria, GeoArabia 16, 3, 95-124.

Calon T.J., Aksu A.E., Hall J. (2005a) The Neogene evolution of the Outer Latakia Basin and its extension into the Eastern Mesaoria Basin (Cyprus), Eastern Mediterranean, Mar. Geol. 221, 1-4, 61-94. https://doi.org/10.1016/j.margeo.2005. 03.013 . 
Calon T.J., Aksu A.E., Hall J. (2005b) The Oligocene-Recent evolution of the Mesaoria Basin (Cyprus) and its western marine extension, Eastern Mediterranean, Mar. Geol. 221, 1-4, 95-120. https://doi.org/10.1016/j.margeo.2005.03.012.

Chanvry E., Deschamps R., Joseph P., Puigde F.C., PoyatosMora M., Serra K., Garcia D., Teinturier S. (2018) The influence of intrabasinal tectonics in the stratigraphic evolution of piggyback basin fills: Towards a model from the TrempGraus-Ainsa Basin (South-Pyrenean Zone, Spain), Sediment. Geol. 377, 34-62. https://doi.org/10.1016/j.sedgeo.2018. 09.007.

Dargahi S., Arvin M., Pan Y., Babaei A. (2010) Petrogenesis of post-collisional A-type granitoids from the Urumieh-Dokhtar magmatic assemblage, Southwestern Kerman, Iran: Constraints on the Arabian-Eurasian continental collision, Lithos 115, 1-4, 190-204. https://doi.org/10.1016/j.lithos.2009.12.002.

Dercourt J.R., Zonenshain L.P., Ricou L.E., Kazmin V.G., Le Pichon X., Knipper A.L., Grandjacquet C., Sbortshikov I.M., Geyssant J., Lepvrier C., Pechersky D.H., Boulin J., Sibuet J.C., Savostin L.A., Sorokhtin O., Westphal M., Bazhenov M.L., Lauer J.P., Biju-Duval B. (1986) Geological evolution of the tethys belt from the atlantic to the pamirs since the LIAS, Tectonophysics 123, 1-4, 241-315. https://doi.org/10.1016/ 0040-1951(86)90199-X.

Dilek Y., Sandvol E. (2009) Seismic structure, crustal architecture and tectonic evolution of the Anatolian-African Plate Boundary and the Cenozoic Orogenic Belts in the Eastern Mediterranean Region, Geol. Soc. Lond. Spec. Publ. 327, 1, 127-160. https://doi.org/10.1144/SP327.8.

Eaton S. (1987) The sedimentology of mid to late Miocene carbonates and evaporites and in southern Cyprus, $P h D$ Thesis, University of Edinburgh.

Eaton S., Robertson A.H.F. (1993) The Miocene Pakhna Formation, southern Cyprus and its relationship to the Neogene tectonic evolution of the Eastern Mediterranean, Sediment. Geol. 86, 273-296.

Farrell S.G., Eaton S. (1987) Slump strain in the Tertiary of Cyprus and the Spanish Pyrenees. Definition of palaeoslopes and models of soft-sediment deformation, Geol. Soc. Lond. Spec. Publ. 29, 1, 181-196. https://doi.org/10.1144/GSL.SP. 1987.029.01.15.

Fillon C., Huismans R.S., Van Der Beek P., Muñoz J.A. (2013) Syntectonic sedimentation controls on the evolution of the southern Pyrenean fold-and-thrust belt: Inferences from coupled tectonic-surface processes models, J. Geophys. Res.: Solid Earth 118, 10, 5665-5680. https://doi.org/10.1002/jgrb.50368.

Follows E.J. (1992) Patterns of reef sedimentation and diagenesis in the Miocene of Cyprus, Sediment. Geol. 79, 1-4, 225-253. https://doi.org/10.1016/0037-0738(92)90013-H.

Follows E.J. (1996) Tectonic controls miocene reefs related carbonate facies, SEPM Concepts of Sedimentology and Paleontology, pp. 295-315.

Garfunkel Z. (1998) Constraints on the origin and history of the Eastern Mediterranean basin, Tectonophysics 298, 1-3, 5-35. https://doi.org/10.1016/S0040-1951(98)00176-0.

Garfunkel Z. (2004) Origin of the Eastern Mediterranean basin: A reevaluation, Tectonophysics 391, 1-4, 11-34.

Glover C., Robertson A. (1998) Neotectonic intersection of the Aegean and Cyprus tectonic arcs: Extensional and strike-slip faulting in the Isparta Angle, SW Turkey, Tectonophysics 298, 1-3, 103-132. https://doi.org/10.1016/S0040-1951(98)00180-2.

Gorini C., Montadert L., Rabineau M. (2015) New imaging of the salinity crisis: Dual Messinian lowstand megasequences recorded in the deep basin of both the eastern and western Mediterranean, Mar. Pet. Geol. 66, 278-294. https://doi.org/ 10.1016/j.marpetgeo.2015.01.009.

Granot R. (2016) Palaeozoic oceanic crust preserved beneath the eastern Mediterranean, Nat. Geosci. 9, 701-705. https:// doi.org/10.1038/ngeo2784.

Guan Z., Chen K., He M., Zhu J., Zhou F., Yu S. (2016) Recurrent mass transport deposits and their triggering mechanisms in the Kaiping Sag, Pearl River Mouth Basin, Mar. Pet. Geol. 73, 419-432. https://doi.org/10.1016/j.marpetgeo.2016. 03.016 .

Hall J, Aksu A.E., Calon T.J., Yasar D. (2005a) Varying tectonic control on basin development at an active microplate margin: Latakia basin, eastern Mediterranean, Mar. Geol. 221, 15-60.

Hall J., Calon T.J., Aksu A.E.Meade S.R. (2005b) Structural evolution of the Latakia Ridge and Cyprus basin at the front of the Cyprus Arc, Eastern Mediterranean sea, Mar. Geol. 221, 261-297.

Haq B.U., Hardenbol J., Vail P.R. (1988) Chronology of fluctuating sea levels since the Triassic, Science 235, 4793, 1156-1167. https://doi.org/10.1126/science.235.4793.1156.

Harrison R.W. (2008) A model for the plate tectonic evolution of the eastern mediterranean region that emphasizes the role of transform (strike-slip) structures, in: 1st WSEAS International Conference on Environmental and Geological Science and Engineering (EG'08), pp. 153-158.

Harrison R.W., Newell W., Batihanli H., Panayides I., McGeehin J.P., Mahan S., Ozur E., Tsiolakis E., Necdet M. (2004) Tectonic history northern Cyprus, J. Asian Earth Sci. 23, 191-210.

Hawie N., Gorini C., Deschamps R., Nader F.H., Montadert L., Granjeon D., Baudin F. (2013) Tectono-stratigraphic evolution of the northern Levant Basin (offshore Lebanon), Mar. Pet. Geol. 48, 392-410. https://doi.org/10.1016/ j.marpetgeo.2013.08.004.

Jolivet R., Faccenna C. (2000) Mediterranean extension and the Africa-Eurasia collision, Tectonics 19, 6, 1095-1106. https://doi.org/10.1029/2000TC900018.

Kähler G. (1994) Stratigraphy and sedimentology of the Lefkara formation, Cyprus (Paleogene to Early Neogene), PhD Thesis, The University of Southampton.

Kähler G., Stow D.A. (1998) Turbidites and contourites of the Palaeogene Lefkara Formation, southern Cyprus, Sediment. Geol. 115, 1-4, 215-231. https://doi.org/10.1016/S00370738(97)00094-8.

Kinnaird T.C., Robertson A.H.F. (2012) Tectonic and sedimentary response to subduction and incipient continental collision in southern Cyprus, easternmost Mediterranean region, Geol. Soc. Lond. Spec. Publ. 372, 1, 585-614. https://doi.org/ 10.1144/SP372.10.

Kinnaird T.C. (2008) Tectonic and sedimentary response to oblique and incipient continental - continental collision the easternmost Mediterranean (Cyprus), The University of Edinburgh. Available at https://www.era.lib.ed.ac.uk/handle/ $1842 / 3486$.

Lapierre H., Bosch D., Narros A., Mascle G.H., Tardy M., Demant A. (2007) The Mamonia Complex (SW Cyprus) revisited: Remnant of Late Triassic intra-oceanic volcanism along the Tethyan southwestern passive margin, Geol. Magazine 144, 1-19. https://doi.org/10.1017/S0016756806002937.

Lee S.H., Stow D.A.V. (2007) Laterally contiguous, concaveup basal shear surfaces of submarine landslide deposits 
(Miocene), southern Cyprus: Differential movement of subblocks within a single submarine landslide lobe, Geosci. J. 11, $4,315-321$.

Lord A., Harrison R.W., Boudagher-Fadel M.K., Stone B.D., Osman V. (2009) Miocene mass transport sediments, Troodos Massif, Cyprus, Proc. Geol. Assoc. 120, 133-138.

Malpas J., Calon T., Squires G. (1993) The development of a late Cretaceous microplate suture zone in SW Cyprus, Geol. Soc. Lond. Spec. Publ. 76, 1, 177-195. https://doi.org/ 10.1144/GSL.SP.1993.076.01.08.

Malpas J., Xenophontos C., Williams D. (1992) The Ayia Varvara Formation of SW Cyprus: A product of complex collisional tectonics, Tectonophysics 212, 3-4, 193-211. https://doi.org/10.1016/0040-1951(92)90291-D.

Manzi V., Lugli S., Roveri M., F. Dela Pierre, Gennari R., Lozar F., Natalicchio M., Schreiber B.C., Taviani M., Turco E. (2016) The Messinian salinity crisis in Cyprus: A further step towards a new stratigraphic framework for Eastern Mediterranean Basin Res., 207-236. https://doi.org/10.1111/bre.12107.

Martini E. (1971) Standard Tertiary and Quaternary calcareous nannoplankton zonation, in: Farinacci A. (ed), Proceedings 2nd International Conference Planktonic Microfossils, Vol. 2, Ed. Tecnosci., Roma, pp. 739-785.

McCallum J.E., Scrutton R.A., Robertson A.H.F., Ferrari W. (1993) Seismostratigraphy and Neogene-Recent depositional history of the south-central continental margin of Cyprus, Mar. Pet. Geol. 10, 5, 426-438. https://doi.org/10.1016/ 0264-8172(93)90045-T.

Monnet J. (2005) Final Report study of active tectonics in Cyprus for seismic risk mitigation WP8 33, 242.

Montadert L., Nicolaides S., Semb P.H., Lie O. (2014) Petroleum systems offshore Cyprus, in: Marlow L., Kendall C., Yose L. (eds.), Petroleum systems of the Tethyan region, 106, AAPG Memoir, pp. 301-334. https://doi.org/10.1036/ 13431860M1063611.

Morse J.T. (1996) Biostratigraphical constraints (calcareous nannofossils) on the Late Cretaceous to Late Miocene evolution of Cyprus, PhD Thesis, University of Durham.

Muñoz J.A., Beamud E., Fernández O., Arbués P., DinarèsTurell J., Poblet J. (2013) The Ainsa Fold and thrust oblique zone of the central Pyrenees: Kinematics of a curved contractional system from paleomagnetic and structural data, Tectonics 32, 5, 1142-1175. https://doi.org/10.1002/tect.20070.

Orszag-Sperber F., Rouchy J.M., Elion P. (1989) The sedimentary expression of regional tectonic events during the MiocenePliocene Transition in the southern Cyprus basins, Geol. Magazine 126, 3, 291-299. https://doi.org/10.1017/ S001675680002238X.

Papadimitriou N., Gorini C., Nader F.H., Deschamps R., Symeou V., Lecomte J.C. (2018) Tectono-stratigraphic evolution of the western margin of the Levant Basin (offshore Cyprus), Mar. Pet. Geol. 91, 683-705. https://doi.org/ 10.1016/j.marpetgeo.2018.02.006.

Papazachos B.C., Papaioannou C.H.A. (1999) Lithospheric boundaries and plate motions in the Cyprus area, Tectonophysics 308, 193-204.

Payne A.S., Robertson A.H.F. (2000) Structural evolution and regional significance of the Polis graben system western Cyprus, in: Third International Conference on the Geology of the Eastern Mediterranean, pp. 45-59.

Payne A.S., Robertson A.H.F. (1995) Neogene supra-subduction zone extension in the west Cyprus Polis graben system, J. Geol. Soc. 152, 4, 613-628. https://doi.org/10.1144/gsjgs.152.4.0613.
Poole A.J., Robertson A.H.F. (2000) Quaternary marine terrace and aeolianites in coastal south and west Cyprus: Implications for regional uplift and sea-level change, in: I. Panayides, C. Xenophontos, J. Malpas (eds), Proc. Third International Conference on the Geology of the Eastern Mediterranean, pp. 105-123.

Poole A.J., Robertson A.H.F (1998) Pleistocene fanglomerate deposition related to uplift of the Troodos Ophiolite, Cyprus, in: Robertson A.H.F, Emeis K.-C, Camerlenghi A. (eds), Proc. ODP, Sci. Results, 160, Ocean Drilling Program, College Station, TX, pp. 545-566

Poole A.J., Robertson A.H.F. (1991) Quaternary uplift and sea-level change at an active plate boundary, Cyprus, J. Geol. Soc. 148, 909-921. https://doi.org/10.1144/gsjgs. 148.5.0909.

Reiche S., Hübscher C., Ehrhardt A. (2016) The impact of salt on the late Messinian to recent tectonostratigraphic evolution of the Cyprus subduction zone, Basin Res. 28, 5, 569-597. https://doi.org/10.1111/bre.12122.

Robertson A.H.F. (1977) The origin and diagenesis of cherts from Cyprus, Sedimentology 24, 1, 11-30. https://doi.org/ 10.1111/j.1365-3091.1977.tb00117.x.

Robertson A.H.F. (1998a) Mesozoic-Tertiary tectonic evolution of the easternmost Mediterranean area: integration of marine and land evidence, in: A.H.F. Robertson, K.-C. Emeis, C. Richter, A. Camerlenghi (eds), Proc. ODP, Sci. Results, 160, Ocean Drilling Program, College Station, TX, pp. 723-782. https://doi.org/10.2973/odp.proc.sr.160.061.1998.

Robertson A.H.F. (1998b) Tectonic significance of the Eratosthenes Seamount: A continental fragment in the process of collision with a subduction zone in the eastern Mediterranean (Ocean Drilling Program Leg 160), Tectonophysics 298, 1-3, 63-82. https://doi.org/10.1016/S00401951(98)00178-4.

Robertson A.H.F., Fleet A.J. (1976) The origins of rare earth's in metalliferous sediments of the Troodos Massif. Cyprus, Earth Planet. Sci. Lett. 28, 3, 385-394. https://doi.org/ 10.1016/0012-821X(76)90200-4.

Robertson A.H.F., Woodcock N. (1979) Mamonia complex, southwest Cyprus: Evolution and displacement of a Mesozoic continental margin, Geol. Soc. Am. Bull. 90, 651-665.

Robertson A.H.F., Woodcock N.H. (1986) The role of the Kyrenia Range Lineament, Cyprus, in the geological evolution of the eastern mediterranean area, Philos. Trans. R. Soc. A: Math. Phys. Eng. Sci. 317, 1539, 141-177. https://doi.org/ 10.1098/rsta.1986.0030.

Robertson A.H.F., Xenophontos C. (1993) Development of concepts concerning the Troodos ophiolite and adjacent units in Cyprus, in: H.M. Prichard, T. Alabaster, T. Harris (eds),Magmatic Processes and Plate Tectonics, Geological Society of Special Publication, London, 70, 85-119. https://doi.org/10.1144/GSL.SP.1993.076.01.05.

Robertson A.H.F., Clift P.D., Degnan P.J., Jones G. (1991) Palaeogeographic and palaeotectonic evolution of the Eastern Mediterranean Neotethys, Palaeogeogr. Palaeoclimatol. Palaeoecol. 87, 1-4, 289-343. https://doi.org/10.1016/00310182(91)90140-M.

Robertson A.H.F., Karamata S., Saric K. (2009) Overview of ophiolites and related units in the Late PalaeozoicEarly Cenozoic magmatic and tectonic development of Tethys in the northern part of the Balkan region, Lithos 108, 1-4, 1-36. https://doi.org/10.1016/j.lithos.2008.09.007. 
Robertson A.H.F., Parlak O., Ustaomer T. (2012) Overview of the Palaeozoic-Neogene evolution of Neotethys in the Eastern Mediterranean region (southern Turkey, Cyprus, Syria), Pet. Geosci. 18, 4, 381-404. https://doi.org/10.1144/petgeo2011091.

Sage L., Letouzey J. (1990) Convergence of the African and Eurasian plate in the eastern mediterranean, in: Letouzey J. (ed), Petroleum and tectonics in mobile Belts, Editions Technip, Paris, pp. 49-68.

Sissingh W. (1977) Biostratigraphy of Cretaceous calcareous nannoplankton, Geol. Mijnbouw 56, 1, 37-65.

Sissingh W. (1978) Microfossil biostratigraphy and stagestratotypes of the Cretaceous, Geol. Mijnbouw 57, 3, 433-440.

Stampfli G.M., Borel G.D. (2002) A plate tectonic model for the Paleozoic and Mesozoic constrained by dynamic plate boundaries and restored synthetic oceanic isochrons, Earth Planet. Sci. Lett. 196, 1-2, 17-33. https://doi.org/10.1016/ S0012-821X(01)00588-X.

Stow D.A.V., Lovell J.P.B. (1979) Contourites: Their recognitionin modem and ancient sediments, Earth Sci. Rev. 14, 251-291.

Stow D.A.V., Braakenburg N.E., Xenophontos C. (1995) The Pissouri Basin fan-delta complex, southwestern Cyprus, Sediment. Geol. 98, 1-4, 245-262. https://doi.org/10.1016/ 0037-0738(95)00035-7.
Stow D.A.V., Kahler G., Reeder M. (2002) Fossil contourites: Type example from an Oligocene palaeoslope system, Cyprus, Geol. Soc. Lond. Mem. 22, 443-455.

Swarbrick R.E., Naylor M.A. (1980) The Kathikas Melange, SW Cyprus; Late Cretaceous submarine debris flows, Sedimentology 27, 1, 63-78.

Symeou V., Homberg C., Nader F., Darnault R., Lecomte J.C., Papadimitriou N. (2017) Longitudinal and temporal evolution of the tectonic style along the Cyprus Arc system, assessed through 2-D reflection seismic interpretation: Tectonic style of the Cyprus Arc system, Tectonics 37, 30-47. https://doi.org/ 10.1002/2017TC004667.

Urquhart E., Banner F.T. (1994) Biostratigraphy of the supraophiolite sediments of the Troodos Massif, Cyprus: The Cretaceous Perapedhi, Kannaviou, Moni and Kathikas formations, Geol. Magazine 131, 4, 499-518. https://doi.org/10.1017/S0016756800012127.

Welford K., Hall J., Huebscher C., Reiche S., Louden K. (2015) Crustal seismic velocity structure from Eratosthenes Seamount to Hecataeus Rise across the Cyprus Arc, eastern Mediterranean, Geophys. J. Int. 200, 935-953. https://doi.org/10.1093/gji/ggu447.

Zoetemeijer R., Cloetingh S., Sassi W., Roure F. (1993) Modelling of piggyback-basin stratigraphy: Record of tectonic evolution, Tectonophysics 226, 1-4, 253-269. https://doi.org/10.1016/ 0040-1951(93)90121-Y. 